FLORA NORTHERN IOWA PEAT BOGS

BY

L. H. PAMMEL 



\section{FLORA OF NORTHERN IOWA PEAT BOGS}

BY L. H. PAMMEL

\section{CONTENTS}

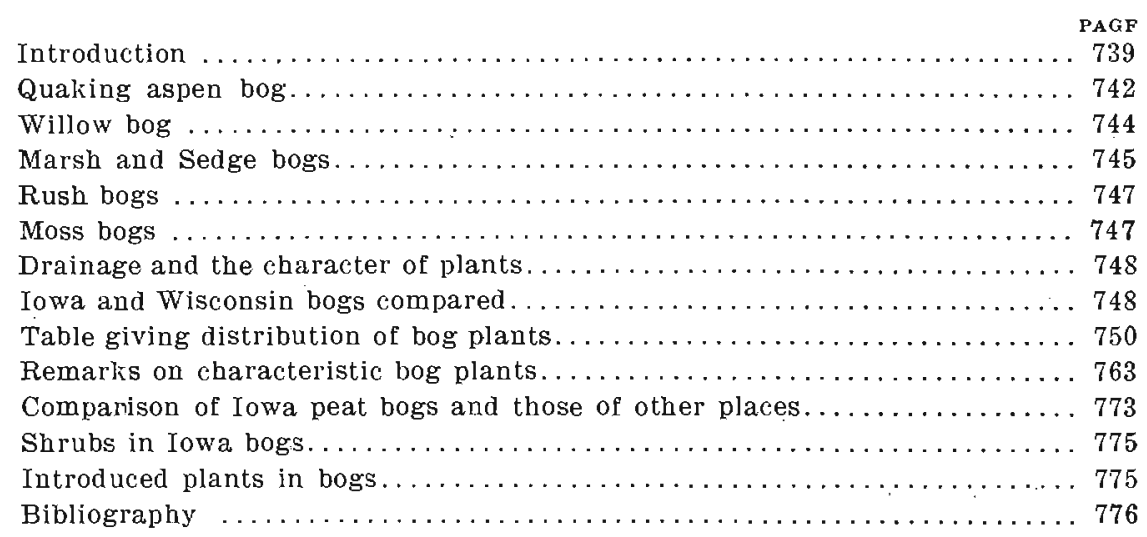





\section{CHAPTER VII}

\section{FLORA OF NORTHERN IOWA PEAT BOGS}

The subject of plants that occur in peat bogs has been discussed in a considerable number of papers both in Europe and America. The most exhaustive and best of recent articles is that by Charles A. Davis on Peat in Michigan. ${ }^{.}$Some of the earlier important publications in the same line were by Shaler on the Fresh Water Morasses of the United States, ${ }^{2}$ by Lesquereux on the Dismal Swamp, and by Kearney on the same swamp.'

Many of the geological text books refer to the formation of peat by sphagnum mosses; but, as stated by Davis, few geologists have heretofore realized the importance of other plants in the formation of peat. Winchell is, however, an exception to these and, as early as 1860, recognized the fact that many other aquatic plants take part in peat making.

Few American botanists have made so detailed a study of the peat flora as has Davis. Of the more important contributions on the subject from botanists in our own country, mention may be made of the papers by Cowles," Coulter," MacMillan," Whitford, ${ }^{8}$ Kearney, ${ }^{2}$ Atkinson, ${ }^{10}$ Mills, ${ }^{1}$ Pieters, ${ }^{12}$ Transeau, ${ }^{13}$, Harshberger, ${ }^{14}$ Olsson-Seffer, ${ }^{15}$ and Weld.$^{10}$ A number of European investigators have made quite exhaustive studies of peat bog floras; of these we may mention Schimper, ${ }^{17}$ Früh,${ }^{10}$ Koller,${ }^{10}$ Eiseln, ${ }^{20}$ Sendtner, ${ }^{21}$ Fischer-Benzon, ${ }^{20}$ Weber, ${ }^{23}$ Christ, ${ }^{24}$ Drude, ${ }^{25}$ and Jens Holmboe, the Scandinavian, who has given an excellent review of the work done in this line by Blytt, Nathorst, Rekstad, Gunnar, Anderson, Sernander, Schulz, and others.

On the subject of bog flora in Iowa, the writer, ${ }^{20}$ has contributed two notes; there are also notes by Cratty, ${ }^{27}$ and by Shimek. ${ }^{28}$

Davis in his paper on Peat makes three classifications of peat formations. The first according to the form of land surface upon 
which they have been formed. A second classification given by him is based on the development of the deposit. The third classification given by Davis is based on the kinds of plants found in the bog. He records the following types in Michigan.

(1) Elm and Black Ash swamps.

(2) Tamarack swamps, marshes and bogs.

(3) Cedar (Arbor Vitæ) swamps.

(4) Spruce swamps.

(5) Willow and Alder swamps.

(6) Heath (Blueberry, Cranberry and Cassandra) swamps, marshes or bogs.

(7) Grass and Sedge marshes and bogs.

(8) Rush marshes (Cat-tail and Bullrush marshes belong here).

(9) Moss bogs (including Sphagnum bogs).

A classification of the Iowa bogs in the area studied by the writer would include the following:

(1) The Quaking Aspen bog.

(2) Willow bog.

(3) Grass and Sedge marshes.

(4) Rush marshes.

(5) Moss bogs.

It is clear, however, that all of these bogs contain a mixed vegetation of many aquatic or semi-aquatic and even dry land plants.

Transeau, who has made a study of the bog plants of North America, after eliminating those which are merely local, numbers the following fifteen plants: Buckbean (Menyanthes trifoliata), Tall Sedge (Dulichium arundinaceum), Cowberry (Potentilla palustris), Scheuchzeria palustris, Tall Cotton Grass (Eriophorum viridi-carinatum), Sundew (Drosera rotundifolia), Pitcher Plant (Sarracenia purpurea), Small Cranberry (Vaccinium oxycoccus), Creeping Snowberry (Chiogenes hispidula), Wild Rosemary (Andromeda polifolia), Leather-leaf (Chamaedaphne calycillata), Labrador Tea (Ledum groenlandicum), Laurel (Kalmia latifolia), Swamp Birch (Betula pumila), and Tamarack (Larix laricina). In commenting upon this list, Harshberger finds that ten, only, are present in Europe in simi- 
lar habitats. The Dulichium, Sarracenia purpurea, and Kalmia are endemic. The larch and birch are represented in the Old World by closely related species. From the evidence, it is apparent that these plants originated as circumpolar species during pre-glacial times. In Northern Europe, they have found a succession of species. In the lower parts of the bogs, occur traces of an artic flora. The Scotch pine and white birch are also found in the lower layers. In a Wisconsin bog, the writer found a white ash (Fraxinus americana); occasionally some wood has been found in Iowa bogs, this evidently being of post-glacial origin. In a study of the peat flora of the western Wisconsin drift area, but few plants were found to be common to the lișt given by Transeau. These are Menyanthes, Dulichium, Potentilla, Scheuchzeria, and Eriophorum. In addition to these the peat bogs of Wisconsin have Drosera, Sarracenia, Chiogenes, Betula pumila, and Larix. While true bogs may be confined to the Northern Hemisphere, Darwin, however, discovered in the Southern Hemisphere, a bog formation of Astelia pumila, a species of rush. Harshberger mentions the formation of peat bogs on Roan Mountain in North Carolina, Slide Mountain in the Catskills, Mt. Marcy in the Adirondacks, Mt. Mansfield in Vermont, Mt. Washington in New Hampshire, Mt. Katahdin in Maine, and Sierra de Ajusco in Mexico. These are by no means all of the same origin. The writer has found peat bogs of small extent in the Uintah Mountains at 13,000 feet elevation. The bogforming species were a dwarf birch, Betula glandulosa, Eriophorum, Carex, and species of Hypnum. No sphagnum was found in any of these mountains.

Louis A Weld" has given us a picture of the formation of a peat bog and moraine lake in the Huron River Valley of Michigan. He recognizes five zones as follows: (1) Potamogeton zone represented chiefly by the $P$. luceus; (2) Nuphar zone, the $N u$ phar advena giving character to the zone, the Nymphaea odorata being sparingly or recently introduced, and Ceratophyllum demersum and Chara being present; (3) Carex and Sphagnum zone, Carex with six species predominating; the flora of this zone is varied, there being about thirty species such as Dulichium, Eleocharis, Carex filiformis, Potentilla palustris, Eupa- 
torium perfoliatum, etc.; (4) Cassandra zone, advance of shrubs of which Cassandra (Chamaedaphne) is most conspicuous, and with this, the Sphagnums are active in raising the marsh; also Glyceria nervata, Aspidium noveboracense, Sarracenia purpurea, Drosera, Pogonia, etc.; (5) Forest zone, the only tree enduring these conditions being the Tamarack, which advances into the Cassandra zone. Peat does not decompose very readily; it owes its antiseptic properties to the presence of ulmic and humic acids. Hilgard states, in his work on Soils, that the acid reaction is due to ulmic acid which is readily soluble in caustic and carbonated alkalies, and forms insoluble salts with the eartlis and metals: the other part, ulmin, is insoluble in these but through oxidation becomes soluble.

The antiseptic property present during the early stage of peat formation stops the action of bacteria and thus we have a chemical process suggested at this point.

The Iowa peat bogs in the Wisconsin drift area are very different in character than those given for Wisconsin. The Menyanthes, Comarum, Eriophorum, Dulichium and Scheuchzeria are the typical plants mentioned by Transeau.

Elm and Black Ash bogs, as well as Tamarack swamps, Cedar swamps, Spruce swamps, Heath swamps, marshes, and bogs, Alder marshes and Sphagnum bogs are entirely absent in the region under consideration. The bogs of this region by no means have the same origin. Generally speaking trees and woody plants form only a small part of the bog flora.

\section{THE QUAKING ASPEN BOG}

The bogs of Cerro Gordo and Worth counties may be compared with some very typical swamps in Wright and Hamilton counties. Both of these counties are in the Wisconsin drift area, and the swamps are in a more advanced stage than in the north and east. These swamps have materially changed since the surrounding country has been brought into cultivation. That these swamps were once lakes, receiving the water from the surrounding country, admits of no doubt. The old beach line is plainly evident. In the larger of these lakes the outer beach was covered with trees and shrubs. Of this arboreal vegetation 
we may mention Quercus macrocarpa, Ulmus fulva, $U$. americana, Fraxinus pennsylvanica, var. viridis and Tilia americana. There are a few shrubs,-Corylus americana, Rhus glabra, $R$. toxicodendron and Symphoricarpos occidentalis. The smaller lakes are not surrounded by timber or shrubs. The outer beach line, which consists of a sandy gravel and humus, contains Oenothera serrulata, Ceanothus americanus, Onosmodium occidentale, $V$ erbena stricta, V. bracteosa, Lithospermum canescens, $L$. angustifolium, Castilleia sessiliflora, Solidago rigida, S. nemoralis.

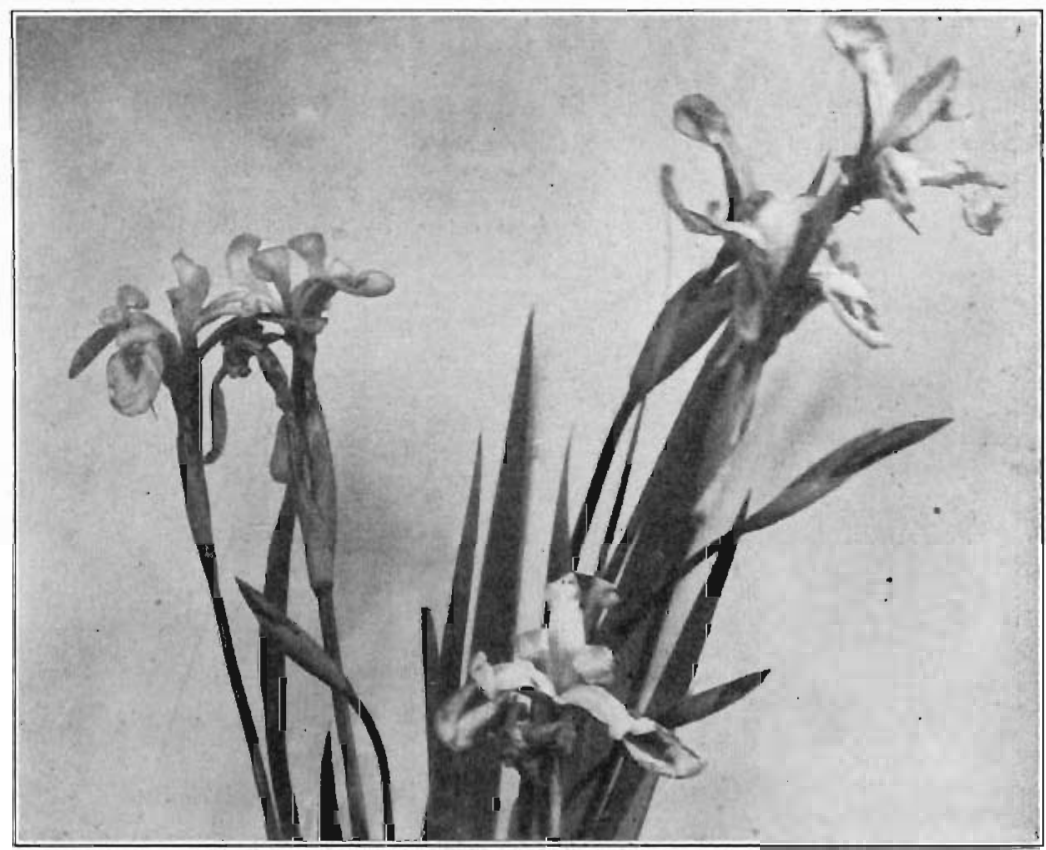

Figure 106. Larger Blue Flag (Iris versicolor L.), a chaŕacteristic bog plant of Iowa.

Poa pratensis is abundantly naturalized. The second beach is thickly covered with Scirpus atrovirens, Glyceria nervata, Thalictrum revolutum, Juncus tenuis, Verbena hastata, and Hordeum jubatum. Formerly Cypripedium candidum was common. The third beach is thickly covered with Carex, Iris versicolor, Lathyrus palustris, Eleocharis palustris, Eupatorium perfoliatum, $E$. purpureum, and Asclepias incarnata. The fourth beach is mostly made up of Calamagrostis canadensis, Carex, Lobelia kalmii, 
Bromus kalmii, and Scutellaria galericulata: This beach is followed by abundant growth of Phragmites communis, Scirpus validus, Typha latifolia, Menyanthes trifoliata and Zizania aquatica. Formerly the center of the swamp was a lake in which Nymphaea advena and Castalia tuberosa abounded, but owing to drying of the lakes these have in most instances disappeared. During the spring and early summer months there is an abundance of water in the small depressions, containing diatoms, des-

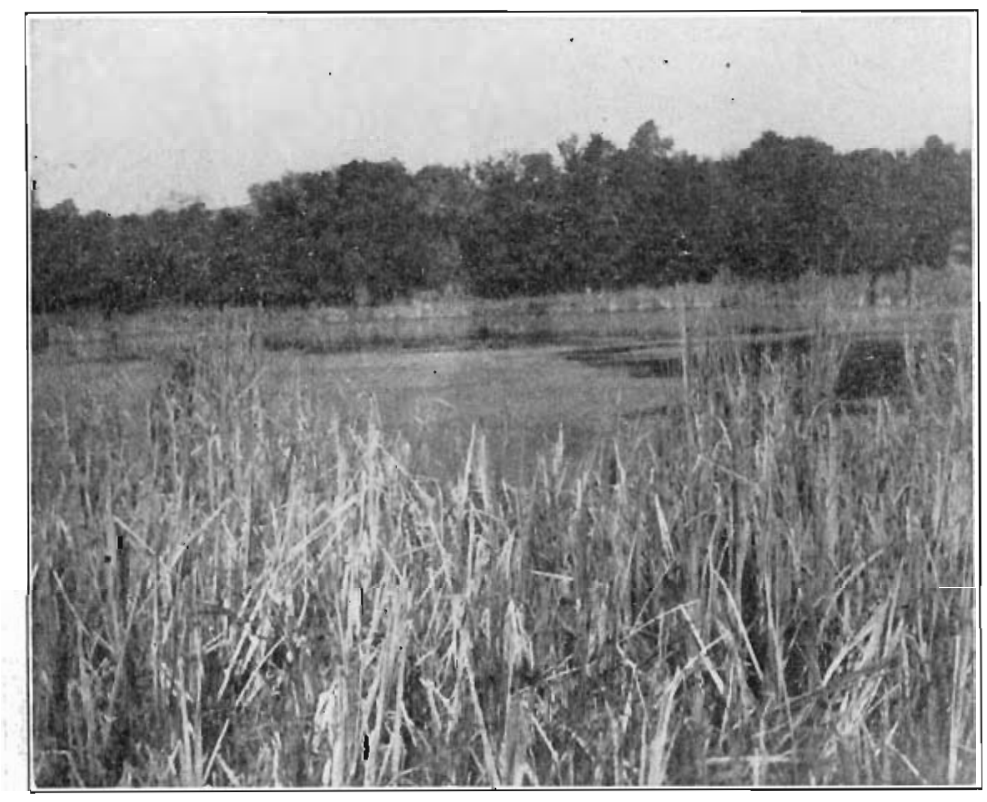

Figure 107. Cat-tall (Typha latifolia L.) on border of swamp in central Iowa. Photo by Charlotte M. King.

mids and other fresh water algæ. The willows, especially Salix discolor and $S$. rostrata, and $S$. candida form an integral part of the flora. The Quaking Aspen occurs in the somewhat higher situations of the bog.

\section{THE WILLOW BOG}

Throughout the Wisconsin and Iowan drift area, willow bogs are frequent but they form only a small part of the peat bog flora. In the Iowan drift or in the driftless area in northeastern 
Iowa in Clayton, Allamakee, and Winneshiek counties, the most important species are the Beaked Willow (Salix rostrata) ; $S$. discolor are usually found along small runs or ditches which have been cut through these marshes or along roadsides. The Myrtle Willow (S. pedicellaris) and $S$. candida, when occurring, are widely scattered over the bog and are therefore a much more integral part of the bog flora than are the other species.

\section{MARSH AND SEDGE BOGS}

- The peat bog near Fertile contains many of the same plants found in the bogs east of Hanlontown. The most conspicuous is the Carex filiformis which is a prevailing and predominant species. Much of the peat is derived from this plant. Associated with this Carex mat there is an abundance of Water Marigold (Bidens trichosperma), Marsh Marigold (Caltha palustris), Parnassia carolinana, Swamp Thistle (Cirsium muticum), Lobelia (Lobelia kalmii), Lousewort (Pedicularis lanceolata), Gentian (Gentiana andrewsii), Fowl Meadow Grass (Glyceria nervata), Spike Rush (Eleocharis palustris), Fringed Gentian (Gentiana crinita), Boneset (Eupatorium perfoliatum), Saxifraga pennsylvanica, White Bellflower (Campanula aparinoides), Galium trifidum, Purple Boneset (Eupatorium purpureum), Poison Hemlock (Cicuta bulbifera and C. maculata), Water Parsnip (Sium cicutaefolium), Wild Timothy (Muhlenbergia racemosa), Greater Dock (Rumex britannica), Meadow Rue (Thalictrum purpurascens), Dulichium (Dulichium arundinaceum), False Dragon Head (Physostegia virginiana), Skullcap (Scutellaria galericulata and S. lateriflora), Tadies Tresses (Spiranthes cernua), Goldenrod (Solidago riddellii), Aster (Aster junceus), Bromegrass (Bromus kalmii and B. ciliatus), Buckbean (Menyanthes trifoliata), Cottongrass (Eriophorum viridicarinatum), St. John's Wort (Hypericum virginicum), Beech Fern (Aspidium thelypteris), Fragrant Orchis (Habenaria leucophaea), and an abundance of Blue Joint Grass (Calamagrostis canadensis and C. inexpansa). Many other plants occur and no doubt partake in the formation of the peat. Of recent introductions mention may be made of Smaller Ragweed (Ambrosia artemisiifolia), Smartweed (Polygonum pennsylvanicum and P. lapathifolium), Sunflower (Heli- 
anthus grosseserratus), Bluegrass (Poa pratensw), Red Top (Agrostis alba), Boot Jack (Bidens frondosa), Aster (Aster salicifolius, A. novae-angliae, A. novi-belgii), Solidago serotina.

When the drainage has been carried on to a much further extent as in some of the bogs in Winnebago and Hancock counties, it may become densely covered with Bidens cernuc. One

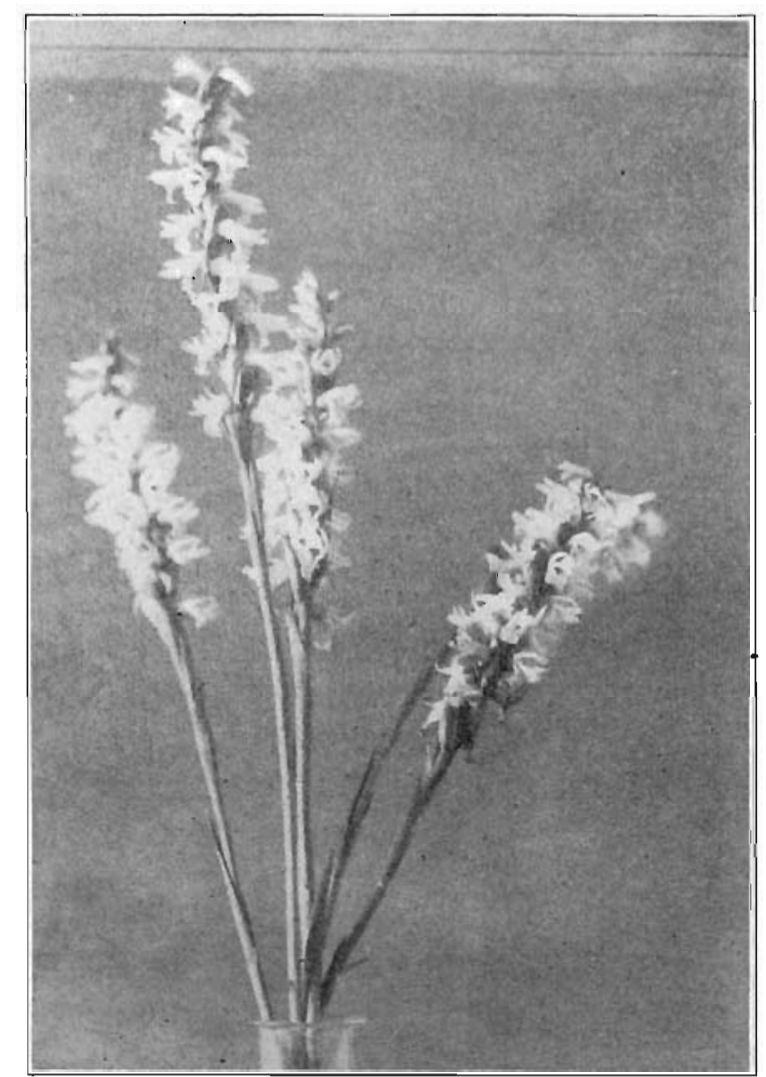

Figure 108. Ladies' Tresses (Spiranthes cernua (L.) Richard.), a bog plant of northern

whole bog, acres of it, was a golden yellow by the growth of this plant. With it occurred a little of the Cicuta bulbifera.

Although the plants of the various bogs of this type are by no means the same, the most typical plant is the Carex filiformis which was commonly found in the bogs of Hamilton, Wright, Worth, Winnebago, Cerro Gordo, and Emmet counties. The fol- 
lowing plants also occur in all of these bogs: Cicuta bulbifera, Pedicularis lanceolata, Gentiana crinita, Scutellaria galericulata, Gentiana andrewsii, Campanula aparinoides, Bidens beckii, Menyanthes trifoliata, Hypericum virginicum, Glyceria canadensis, Galium trifidum, Loosestrife (Lythrum alatum).

The bogs of Worth, Cerro Gordo, and Winnebago counties had in addition Cirsium muticum and Saxifraga pennsylvanica, Salix pedicellaris, and eastward the S. candida.

\section{RUSH BOGS}

These bogs are somewhat limited in extent. The whole of the bog near Fertile had been so sufficiently drained that little of the Greater Rush (Scirpus validus) occurred; however, in numerous small bogs in Hamilton, Winnebago, and Wright counties, this rush formed an important part of the flora. Associated with this rush is the Wild Rice (Zizania aquatica) which is abundant in Winnebago, Emmet, and Hamilton counties. In these bogs the water is from a few inches to a foot or more in depth and often it gives away like a regular sphagnum bog, forming a well matted system of roots. The Greater Reed Grass (Phragmites communis) is abundant. The Yellow Water Lily (Nymphaea advena), and White Water Lily (Castalia tuberosa) are abundant, occasionally also Pickerel-weed (Pontederia cordata) and Crowfoot (Ranunculus delphinifolius and $R$. aquatilis var. capillaceus), Saggitaria, Eleocharis palustris, and the E. acicularis growing in mud, and Cicuta bulbifera. The Zizania, Phragmites, Scirpus validus, Nymphaea and Caștalia are characteristic.

\section{MOSS BOGS}

There are none of the typical moss bogs found in this state. The moss found in this state belongs to the genus Hypnum. Sphagnum has not been found anywhere in the bogs of northern Iowa. 


\section{DRAINAGE AND THE CHARACTER OF FLANTS}

Drainage of the peat bogs has been attempted in many places in Towa and in such places a large number of introduced plants have made their appearance. The Small Ragweed (Ambrosia artemisiifolia), Goosefoot (Chenopodium album), Old Witch Grass (Panicum capillare), Pennsylvania Smartweed (Polygonum pennsylvanicum), Pigweed (Amarantus retroflexus), Five-finger (Potentilla monspeliensis), Milkweed (Asclepias syriaca), Boot Jack (Bidens frondosa), and B. discoidea, are representative types. These plants originally did not constitute a part of the bog flora, except in dry years when they appeared. These are seldom found in the sedge mat where the Marigold (Bidens trichosperma) and Swamp Thistle (Cirsium muticum), Myrtle-leaved Willow (Salix pedicellaris) and Lobelia kalmii grow in abundance.

\section{THE IOWA AND WISCONSIN BOGS COMPARED}

Peat bogs like those found in northern Iowa are common in Wisconsin and Minnesota. Many of the Wisconsin bogs do not have shrubs. The Carex filiformis, Cirsium muticum, Saxifraga pennsylvanica, Parnassia parviflora, Pedicularis lanceolata, Caltha palustris, Valeriana edulis, Salix rostrata, S. discolor are the most characteristic features, with an abundant growth of Symplocarpus foetidus and Cornus stolonifera. In other bogs the Sphagnum, Drosera rotundifolia, Sarracenia purpurea, Rynchospora alba, Calopogon pulchellus and Pogonia ophioglossoides are characteristic. A third type is characterized in western Wisconsin by Larix laricina, Cornus stolonifera, Smilacina bifolia, Symplocarpus foetidus; northward with Black Spruce, Balsam Fir, and Arbor Vitæ. Another type is characterized by the presence of Swamp Ash and Elm. The best comparison may be obtained from the accompanying table for different areas in Iowa, Wisconsin and Michigan.

In various bogs both in Wisconsin and Michigan, as well as Iowa, occur plants that are really not typical bog plants; in some instances the species may be a bog plant in Wisconsin, Minnesota, and Michigan, and yet does not occur in bogs in this state. 
Two of the best illustrations of this character are the Common High Bush Cranberry (Viburnum opulus) and the Pyrus arbutifolia which in this state are common upon the limestone rocks along the Yellow river in Allamakee county and along with it such plants as the Balsam Fir (Abies balsamea) and Aconitum. The two species of Dogwood (Cornus amomum and C. paniculata) though occasionally occurring in bogs associated with willows are really not bog plants. The Hop (Humulus lupulus) is abundant in some of the peat bogs along streams in Wisconsin and the Allium tricoccum or Onion is one of the most abundant plants in peat bogs in proximity to the willows in Wisconsin and Minnesota. The Lady Slipper (Cypripedium parviflorum var. pubescens), Populus grandidentata, Ribes floridum, the Virginia Creeper (Psedera quinquefolia), and the Soft Maple (Acer saccharum) are to be regarded as accidental plants rather than a true constituent of the bog flora. The Orchid (Liparis liliifolia) reported from Nichigan is likewise more commonly found on bigher ground. These-plants probably represent later stages of the development of the bog.

For the sake of convenience, I have followed the nomenclature of the Robinson-Fernald edition of Gray's Manual. Miss Harriette Kellogg has compared for me the names used in this work and has arranged the bibliography. 


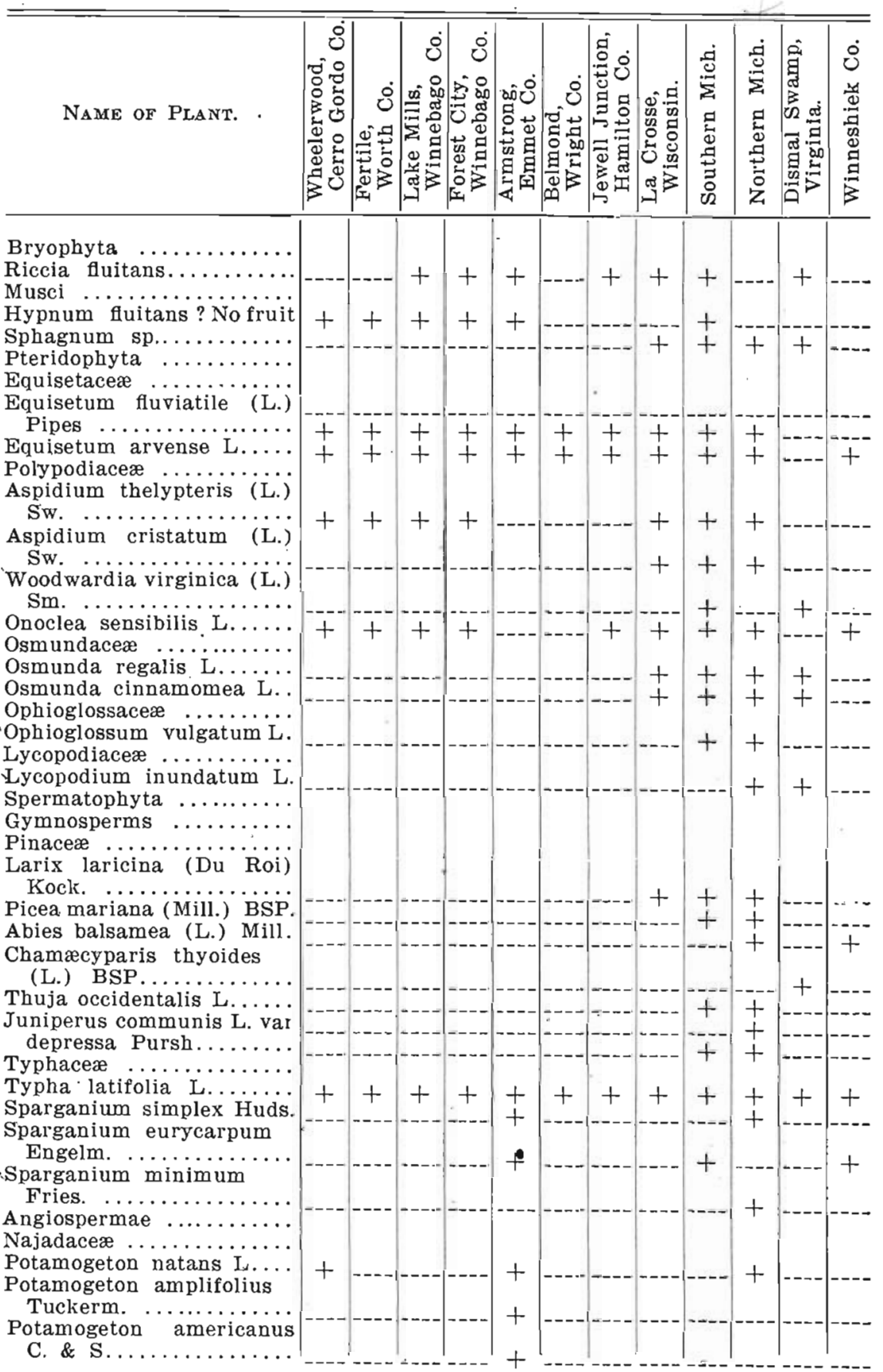




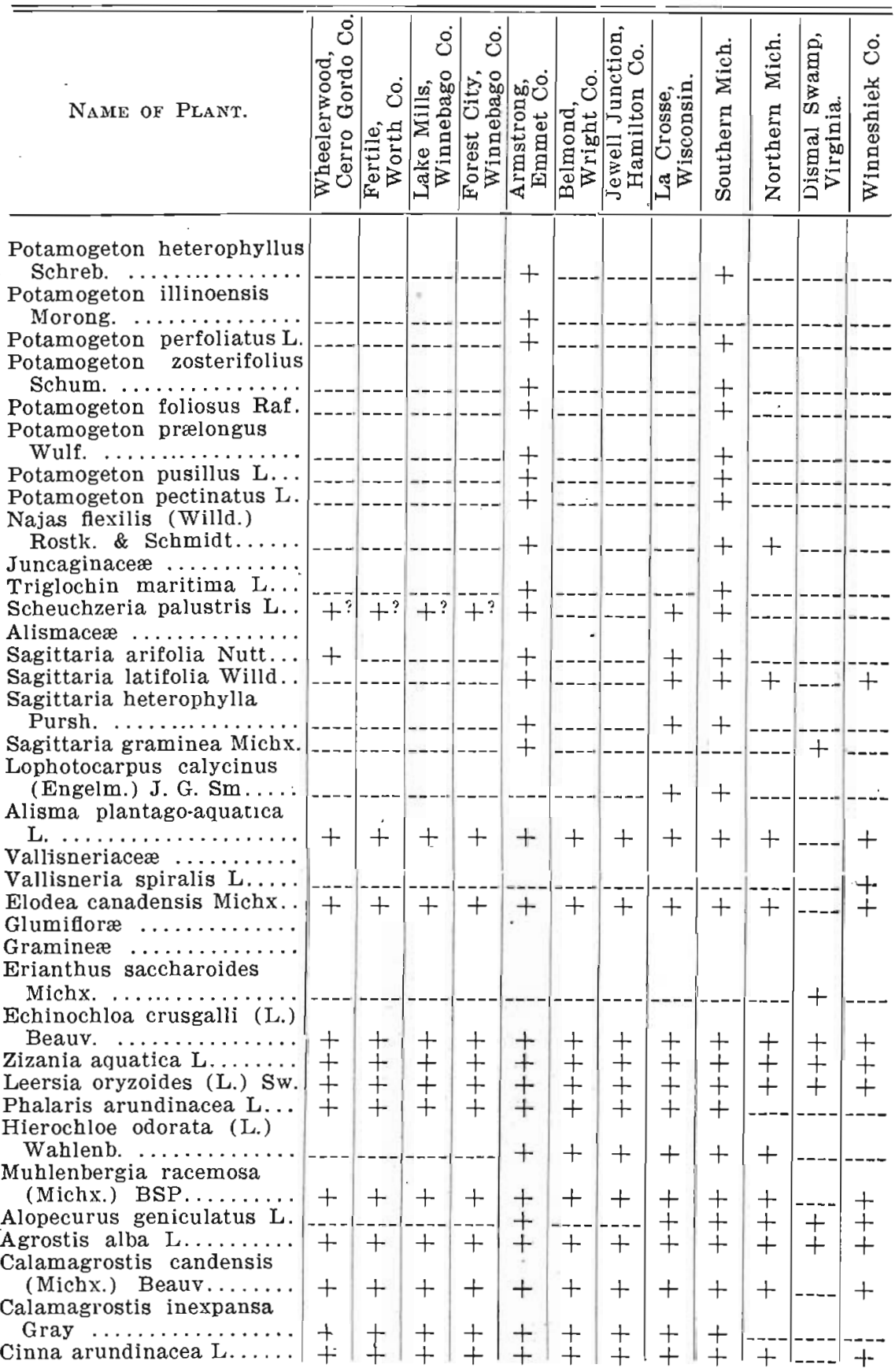




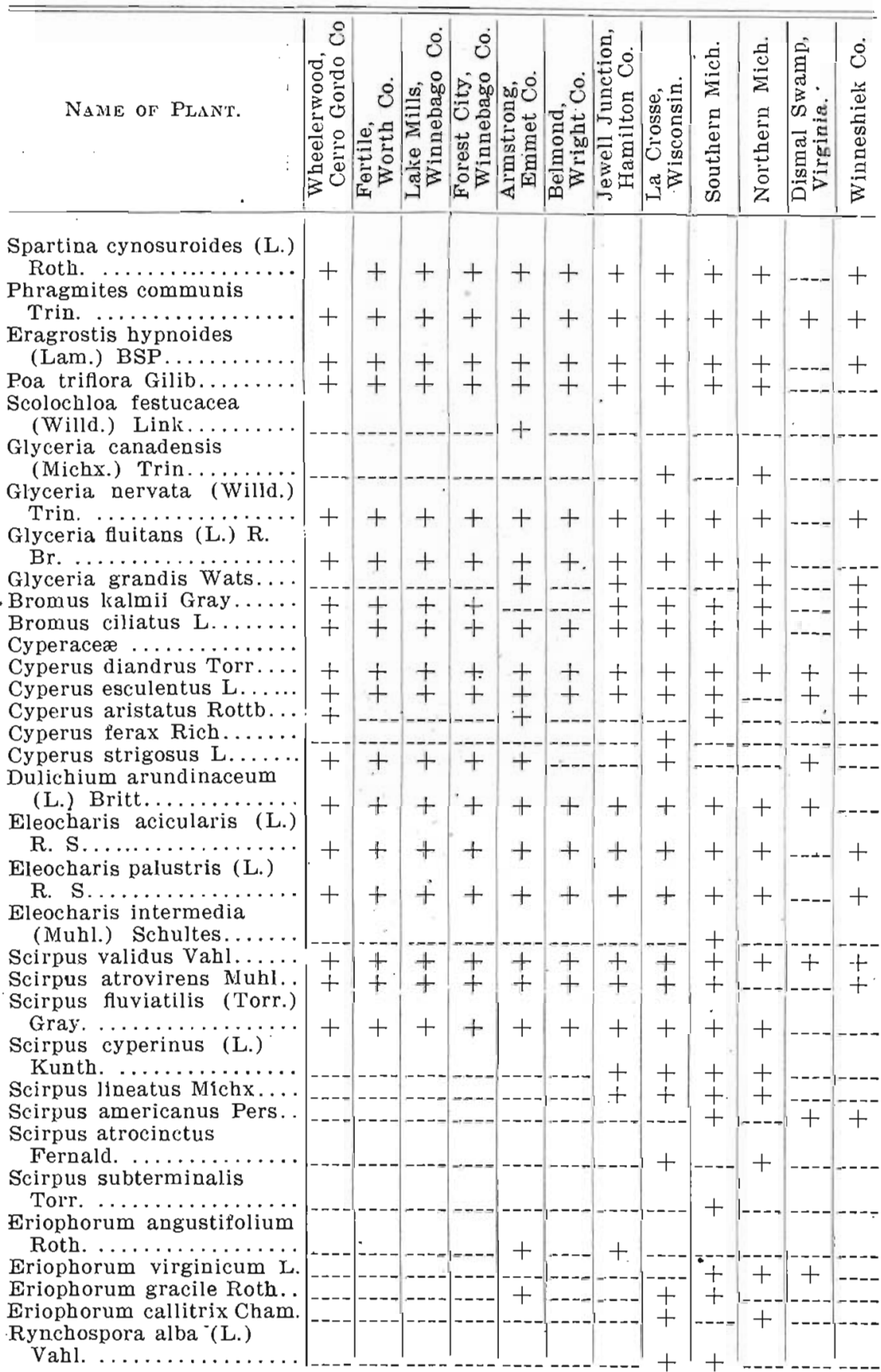




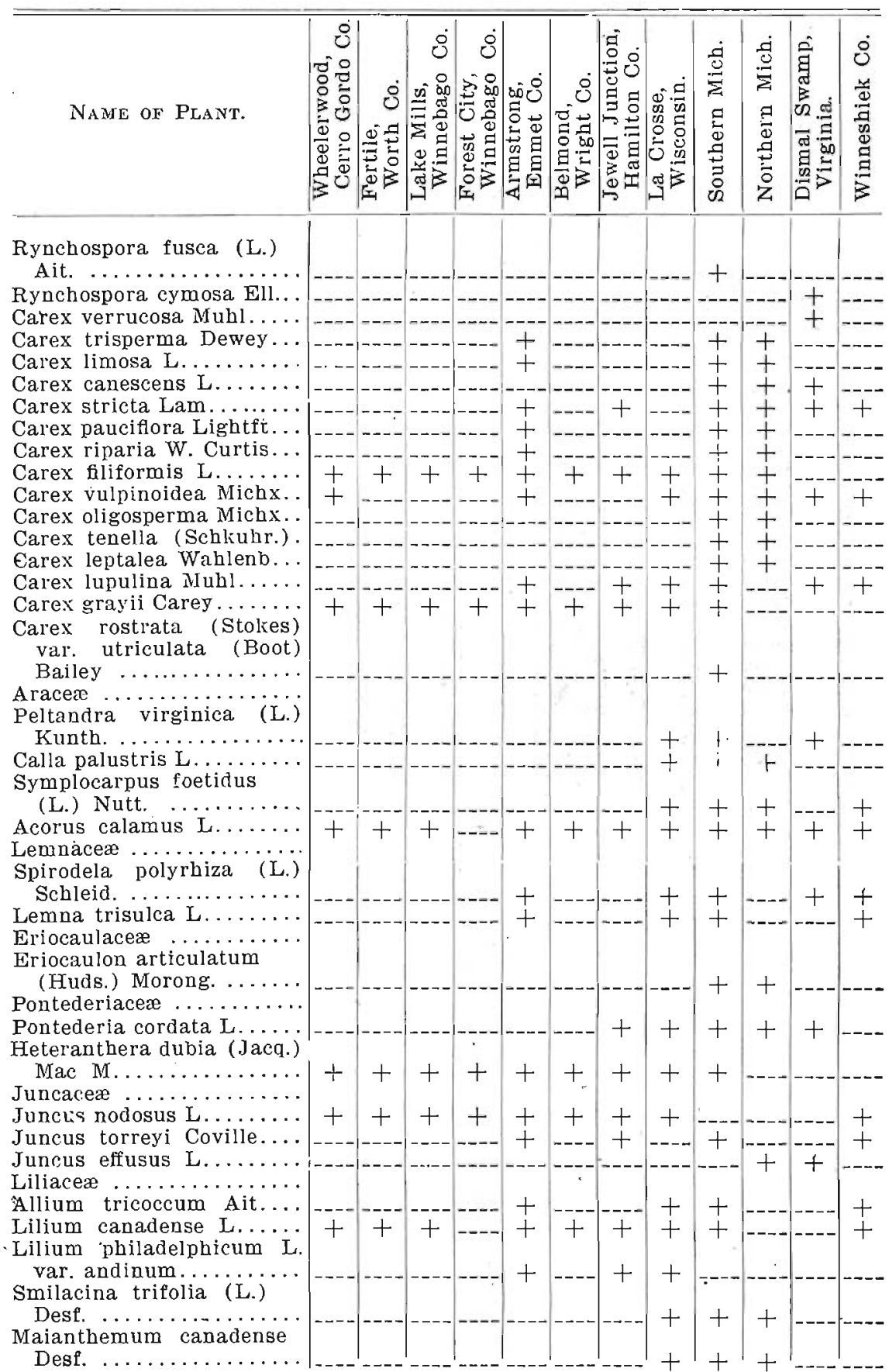

Desf. 


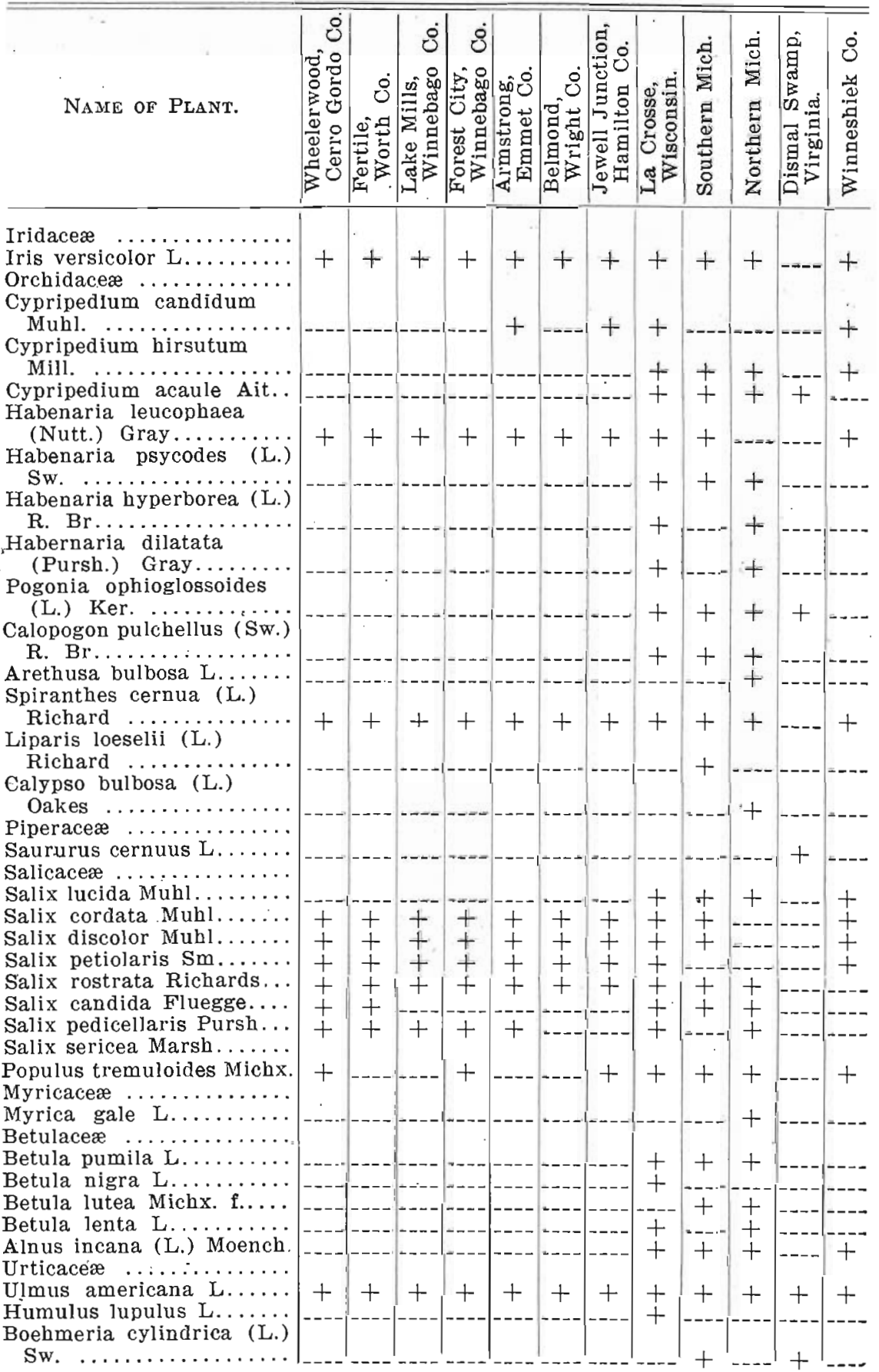




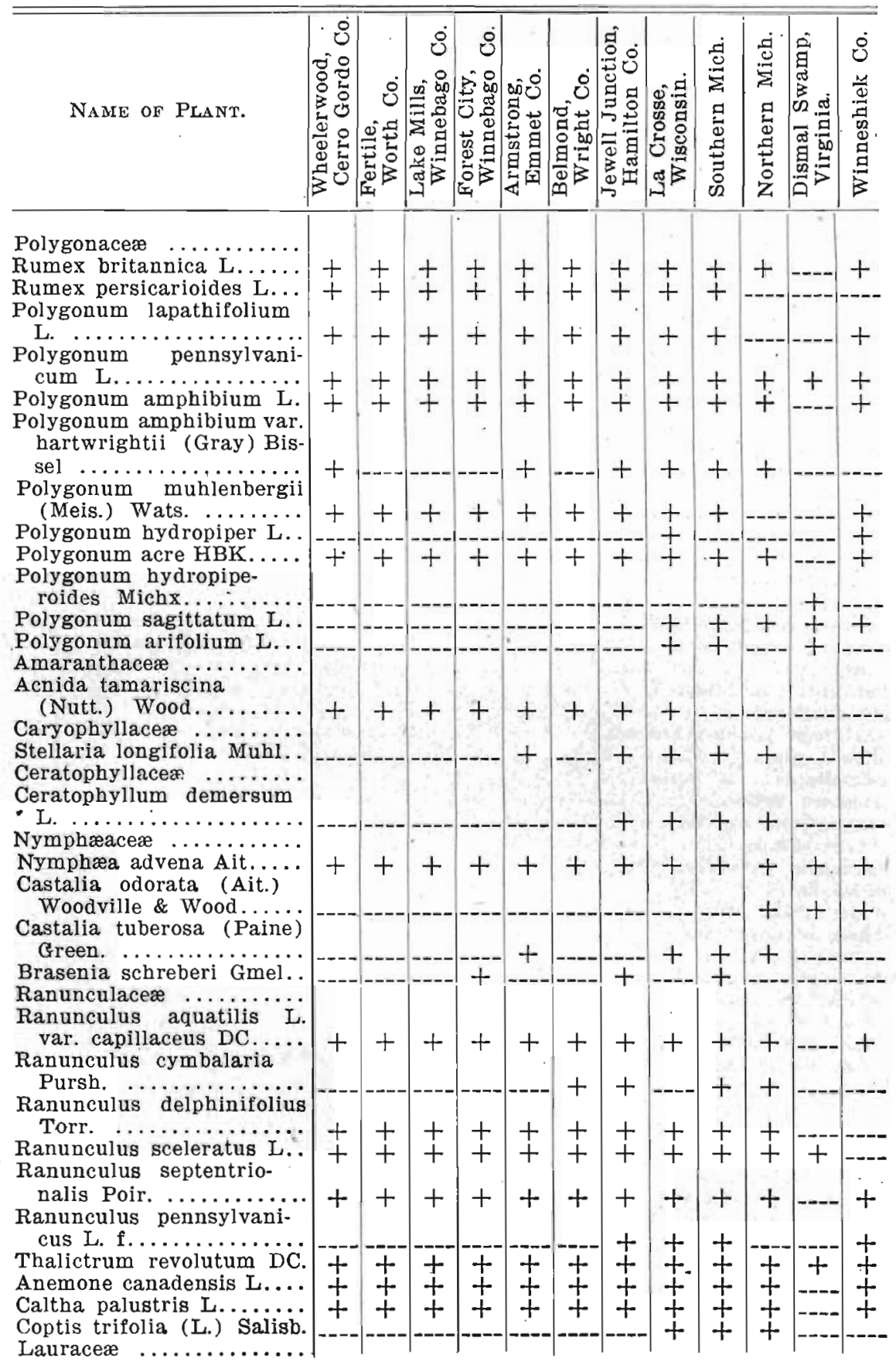


FLORA OF NORTHERN IOWA PEAT BOGS

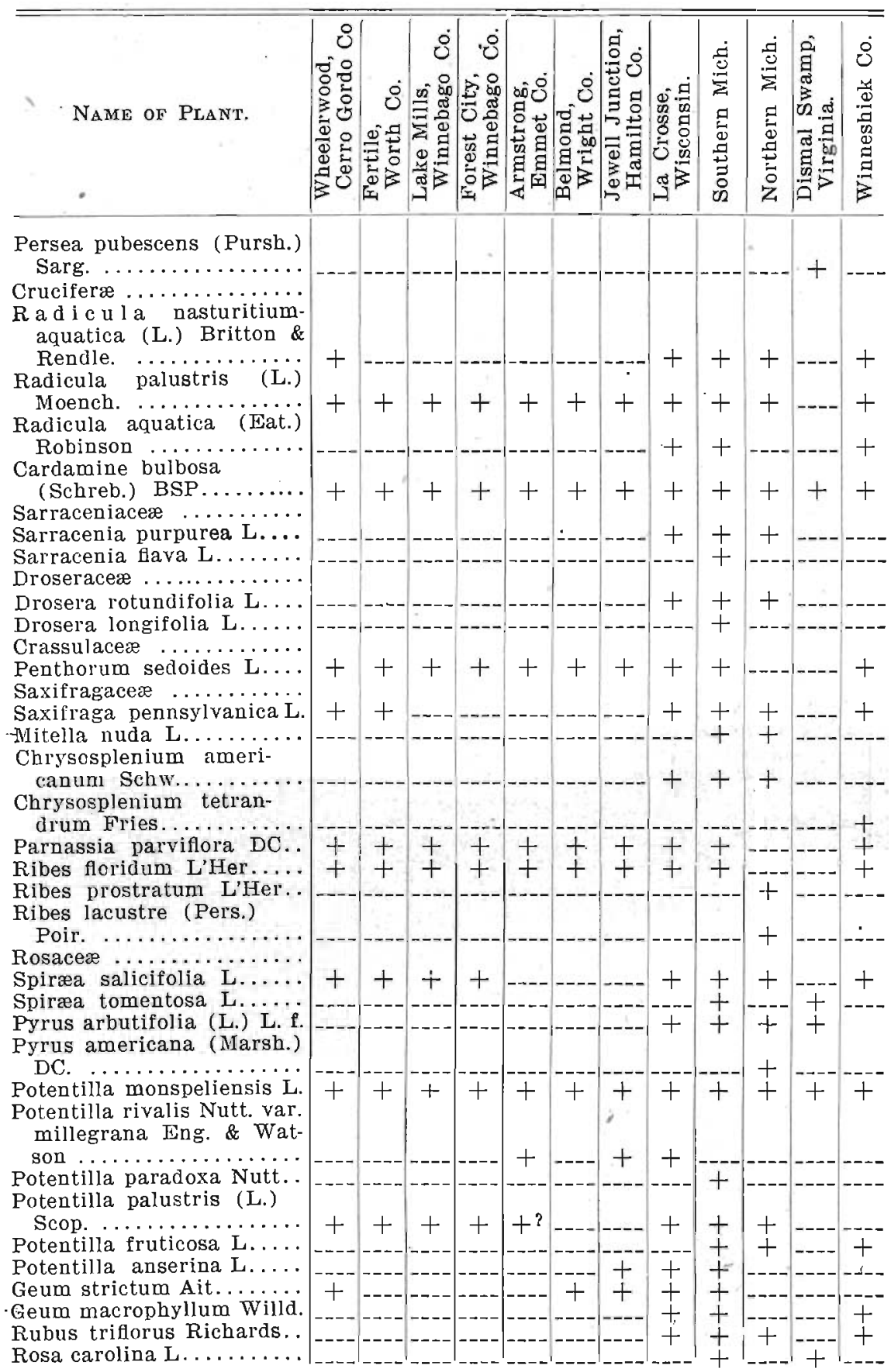




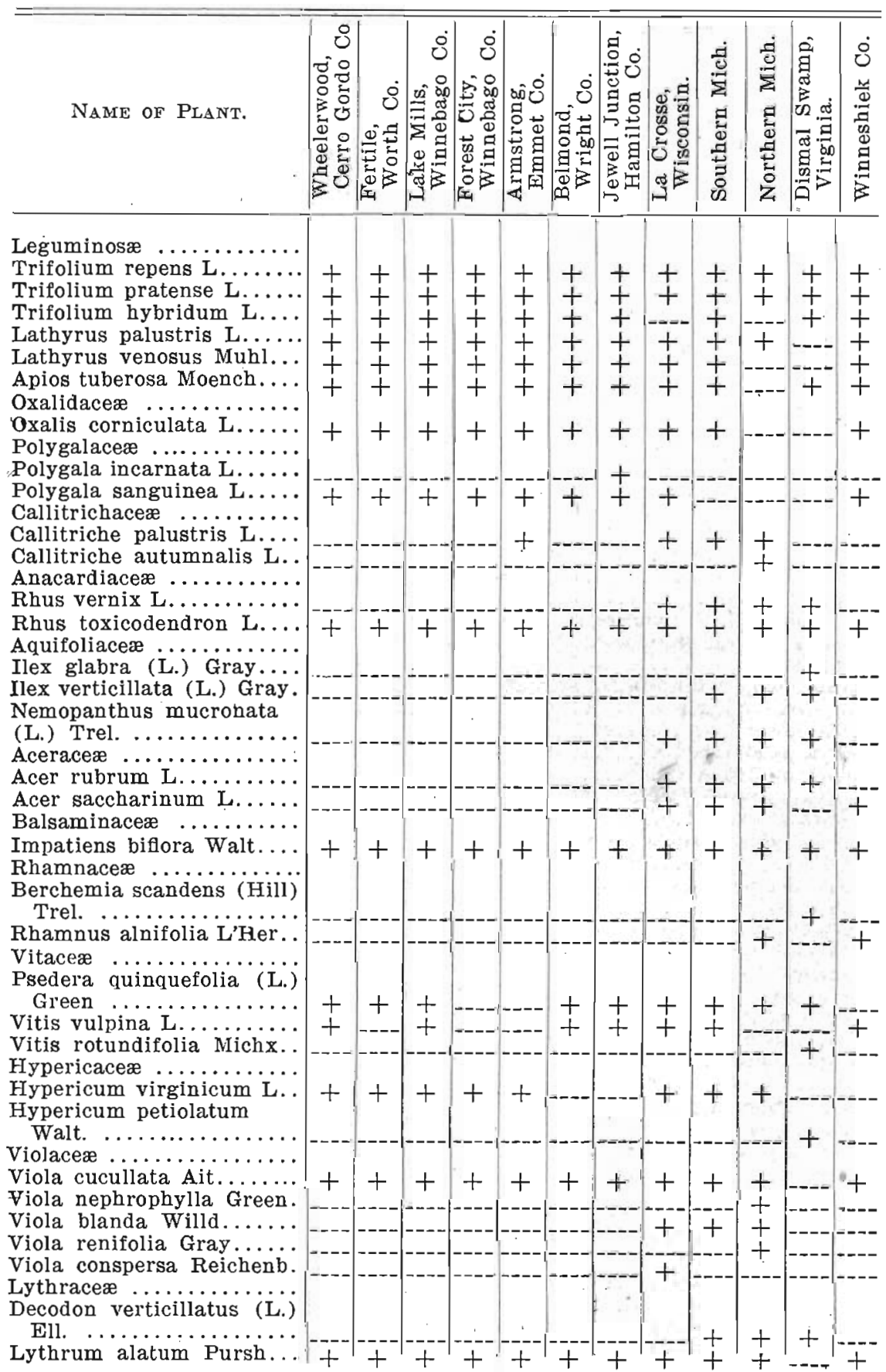




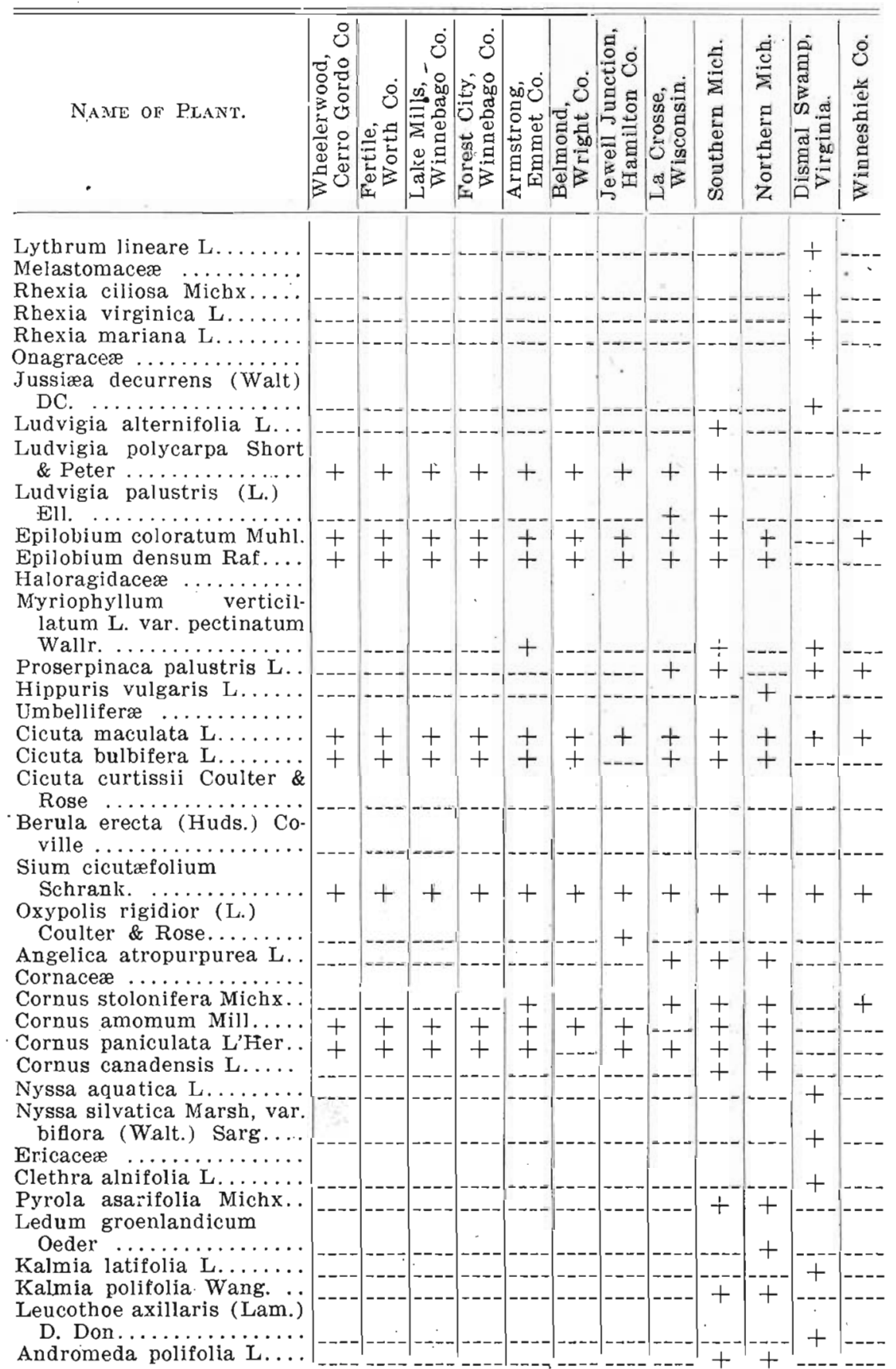




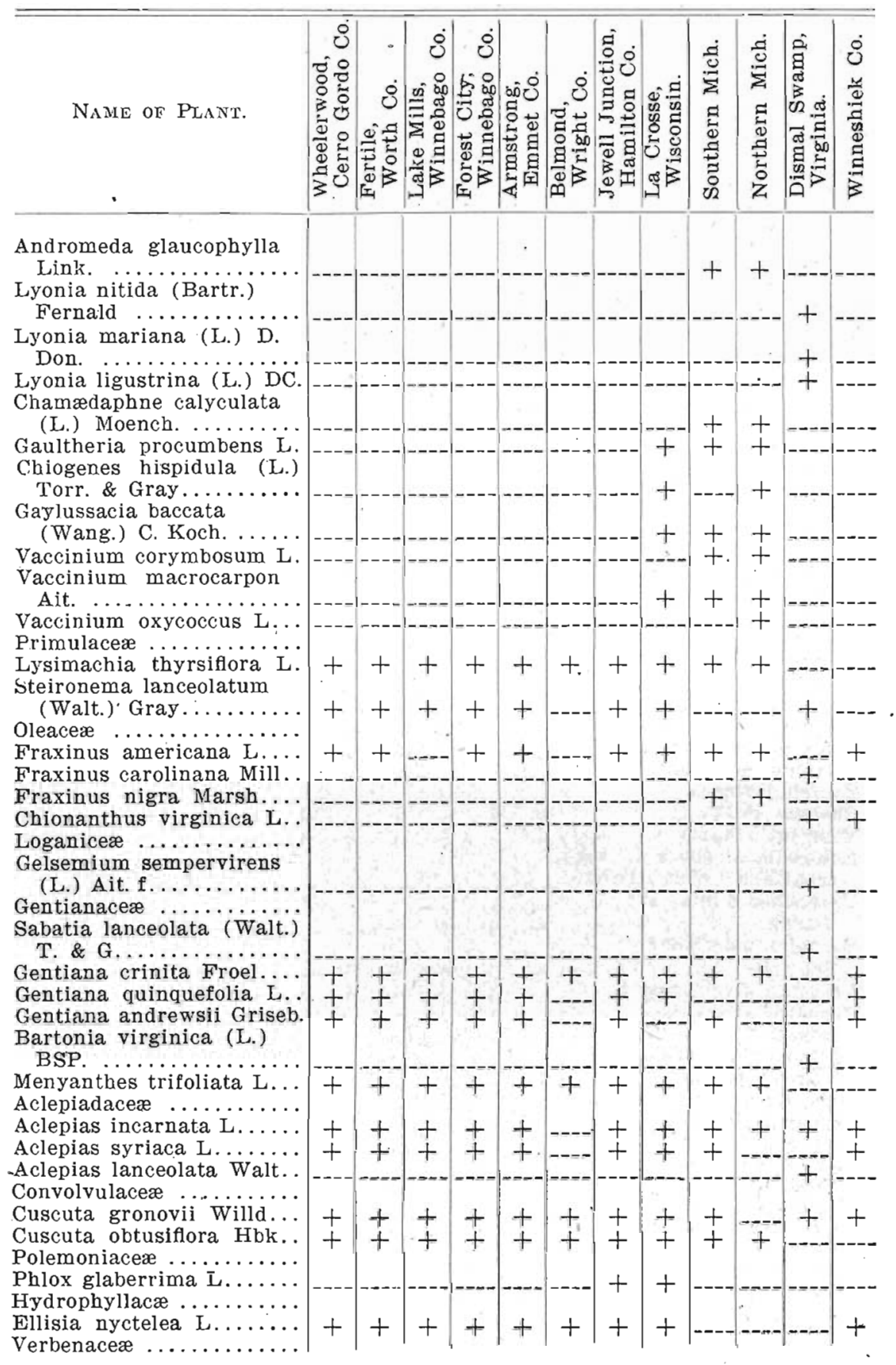




\begin{tabular}{|c|c|c|c|c|c|c|c|c|c|c|c|c|}
\hline Name of Plant. & 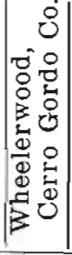 & 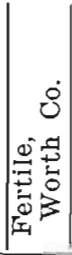 & 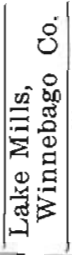 & 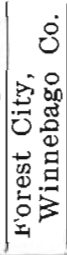 & 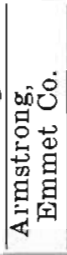 & 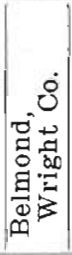 & 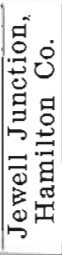 & 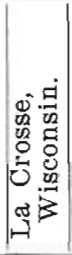 & 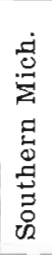 & 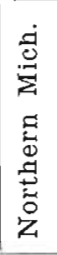 & 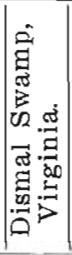 & 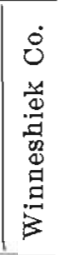 \\
\hline Verbena urticæfolia L,... & + & + & + & + & + & + & + & + & & & + & \\
\hline Verbena hastata L....... & + & + & + & + & + & + & + & + & + & & & + \\
\hline $\begin{array}{l}\text { Teucrium canadense } \mathrm{L} \ldots \\
\text { Teucrium occidentale }\end{array}$ & + & + & + & + & + & + & + & + & + & & & + \\
\hline Gray $\ldots \ldots \ldots \ldots \ldots$ & + & + & + & + & + & + & + & & & & & \\
\hline Scutellaria lateriflora $\mathbf{L} \ldots$ & + & + & + & + & + & & + & + & + & + & + & + \\
\hline $\begin{array}{l}\text { Scutellaria galericulata } L \text {. } \\
\text { Physostegia virginiana }\end{array}$ & + & + & + & + & + & & + & + & + & + & & \\
\hline (L.) Benth. $\ldots \ldots \ldots$. & + & + & + & + & + & + & + & + & + & & + & + \\
\hline Stachys palustris L....... & + & + & + & + & + & & + & + & + & & & + \\
\hline $\begin{array}{l}\text { Stachys tenuifolia Willd. } \\
\text { var. asper (Michx.) Fer- } \\
\text { nald } \ldots \ldots \ldots \ldots \ldots \ldots \ldots\end{array}$ & + & + & + & + & & + & + & + & & + & & + \\
\hline $\begin{array}{l}\text { Lycopus virginicus L...... } \\
\text { Lycopus uniflorus Michx.. }\end{array}$ & + & + & + & + & + & & + & + & + & & & + \\
\hline Lycopus rubellus, Moench. & & & & & & & - & & & & + & \\
\hline $\begin{array}{l}\text { Lycopus americanus, Muhl } \\
\text { Mentha arvensis L. var. }\end{array}$ & + & + & + & + & + & & + & + & + & + & & + \\
\hline canadensis (L.) Briquet. & + & + & + & + & + & + & + & + & + & + & & \\
\hline Mentha spicata L....... & & & & & & & & $T$ & + & + & + & \\
\hline Mentha piperita L....... & & & & & & & & + & + & + & & \\
\hline $\begin{array}{l}\text { Solanaceæ } \ldots \ldots \ldots \ldots \\
\text { Solanum nigrum } \mathrm{L} \ldots \ldots \\
\text { Solanum dulcamara } \mathrm{L} .\end{array}$ & + & $t$ & & & + & & + & + & & & + & + \\
\hline Scrophulariaceæ $\ldots . . . \ldots$ & & & & & & & & & & & + & \\
\hline Chelone glabra L......... & + & + & + & + & & + & + & + & + & & & + \\
\hline $\begin{array}{l}\text { Mimulus ringens L....... } \\
\text { Limosella aquatica } \mathrm{L} \text {. var. } \\
\text { tenuifolia (Wolf.) Pers. }\end{array}$ & + & + & + & + & + & + & t & & + & + & & + \\
\hline Ilysanthes dubia (L.) & & & & & & & & & & & & \\
\hline $\begin{array}{l}\text { Barnh. } \ldots \ldots \ldots \ldots \ldots \\
\text { Veronica americana }\end{array}$ & + & + & + & + & + & & + & + & + & + & + & \\
\hline Schwein $\ldots \ldots \ldots \ldots \ldots$ & + & + & + & + & + & & + & + & + & & & + \\
\hline $\begin{array}{l}\text { Veronica virginicum L... } \\
\text { Veronica anagallis- } \\
\quad \text { aquatica } \mathrm{L} \ldots \ldots \ldots \ldots\end{array}$ & + & + & + & + & + & + & + & + & + & & & + \\
\hline $\begin{array}{l}\text { Gerardia paupercula } \\
\quad \text { (Gray) Britton } \ldots . . .\end{array}$ & & & & & & & & & & & & \\
\hline Gerardia aspera Dougl... & & & & & + & & + & + & + & & + & + \\
\hline $\begin{array}{l}\text { Castilleja coccinea (L.) } \\
\text { Spreng. } \quad \ldots \ldots \ldots \ldots \ldots\end{array}$ & & & & & & & & + & + & & & $t$ \\
\hline Pedicularis lanceolata & & & & & & & & & & & & \\
\hline $\begin{array}{l}\text { Michx. } \ldots \ldots \ldots \ldots \ldots \ldots \\
\text { Lentibulariaceæ } \ldots \ldots \ldots \ldots\end{array}$ & + & + & + & + & + & & + & $t$ & + & + & & + \\
\hline Utricularia vulgaris $L_{\text {. }}$. & & & & & + & & + & + & + & & & + \\
\hline ia bìflora Lam... & & & & & & & & 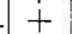 & & & & \\
\hline Utricularia minor L..... & & & & & + & -- & & - & + & & & \\
\hline $\begin{array}{c}\text { Utricularia intermedia } \\
\text { Hayne. } \ldots \ldots \ldots \ldots \ldots \ldots\end{array}$ & & & & & & & & & & & & \\
\hline
\end{tabular}

Plantaginaceæ 


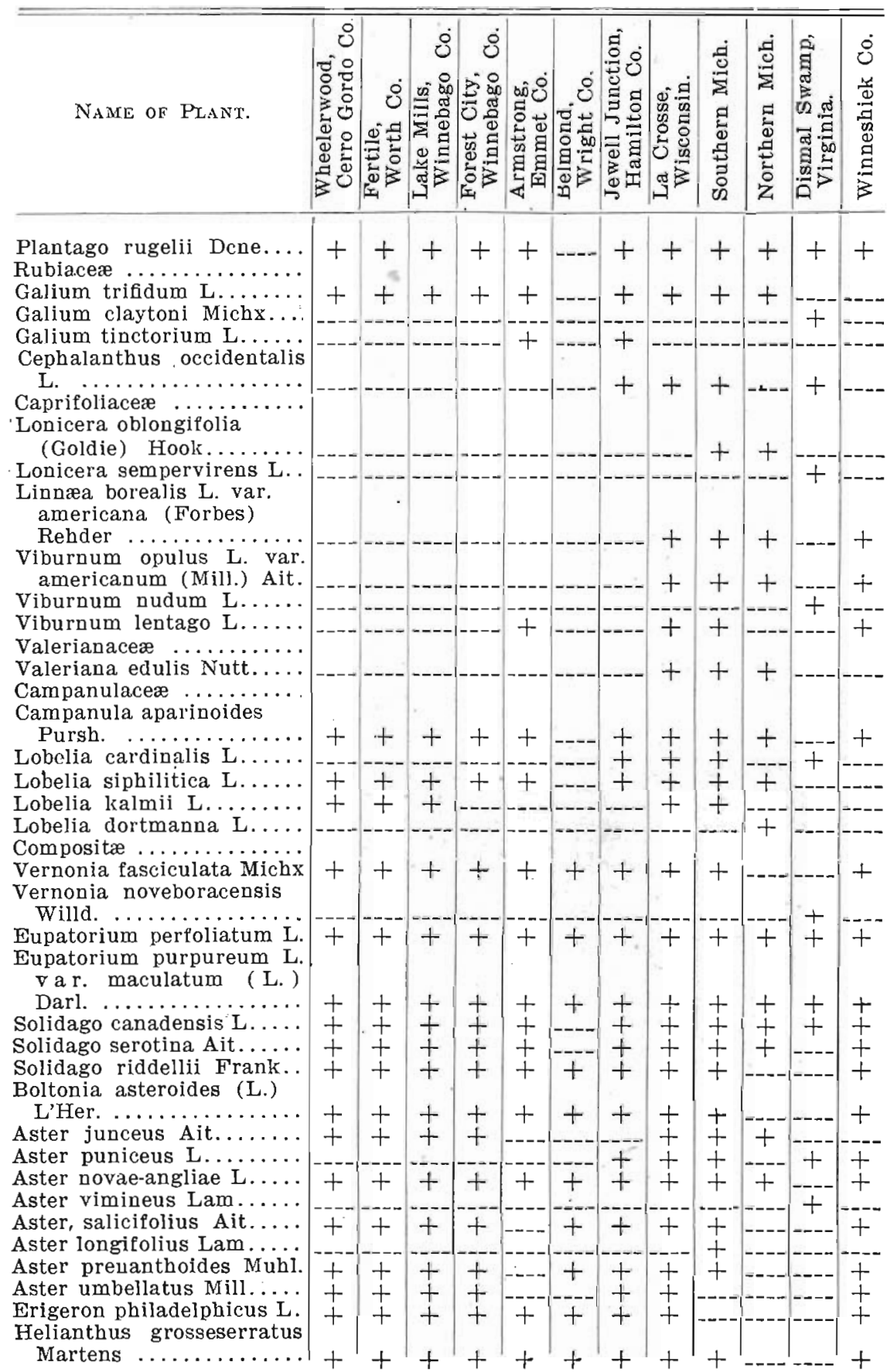




\begin{tabular}{|c|c|c|c|c|c|c|c|c|c|c|c|c|}
\hline NAME OF Plant. & 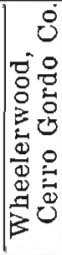 & 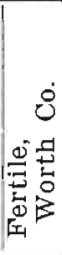 & 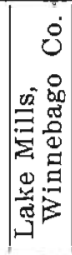 & 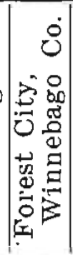 & 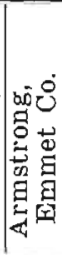 & 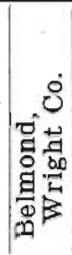 & 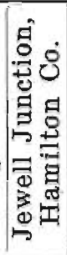 & 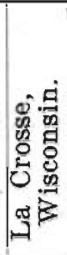 & 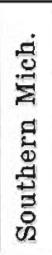 & 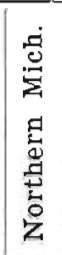 & 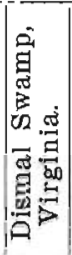 & 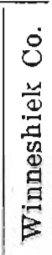 \\
\hline $\begin{array}{c}\text { Bidens discoidea }(\mathrm{T}, \& \mathrm{G} .) \\
\text { Britton } \ldots \ldots\end{array}$ & + & + & & + & + & & & + & & & & \\
\hline Bidens frondosa L....... & + & + & + & + & + & & + & + & + & & + & + \\
\hline Bidens beckii Torr...... & & & & & & + & + & + & + & + & & \\
\hline $\begin{array}{l}\text { Bidens connata Muhl..... } \\
\text { Bidens coronata (L.) }\end{array}$ & + & + & + & + & + & + & + & + & + & & --O- & + \\
\hline 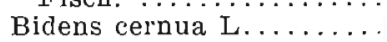 & + & + & + & + & + & + & + & + & + & + & + & + \\
\hline $\begin{array}{l}\text { Bidens trichosperma } \\
\quad(\text { Michx.) Britton ........ }\end{array}$ & + & + & + & + & & & & & & & + & - \\
\hline $\begin{array}{l}\text { Helenium autumnale L } \\
\text { Erechtites hieracifolia (L.) }\end{array}$ & + & + & + & + & + & + & + & + & + & + & --- & + \\
\hline $\begin{array}{l}\text { Raf. } \ldots \ldots \ldots \ldots \ldots \ldots \\
\text { Senecio palustris (L.) } \\
\text { Hook. } \ldots \ldots \ldots \ldots \ldots \ldots\end{array}$ & + & + & + & + & $\begin{array}{l}+ \\
+\end{array}$ & + & + & + & + & & + & + \\
\hline Senecio aureus L........ & + & - & + & + & + & + & + & + & + & & & + \\
\hline Cirsium muticum Michx.. & + & + & + & + & & & -- & + & + & - & & + \\
\hline $\begin{array}{l}\text { Taraxacum officinale } \\
\text { Weber. } \ldots \ldots \ldots \ldots \ldots\end{array}$ & + & + & + & + & + & + & + & + & + & & & + \\
\hline $\begin{array}{l}\text { Prenanthes racemosa } \\
\text { Michx. } \ldots \ldots \ldots \ldots \ldots \ldots\end{array}$ & + & + & + & + & + & + & + & + & & & & + \\
\hline
\end{tabular}




\section{REMARKS ON SOME OF THE CHARACTERISTIC BOG PLANTS}

Aspidium thelypteris. This fern is common in the tamarack bogs, also in the drier sedge bogs of Wisconsin, Michigan, and in northeastern Iowa, as far west as Worth and Winnebago counties. It is infrequent or rare westward. This species, then, may be called a typical peat bog fern. The allied $A$. cristatum does not occur in the peat bogs of northern Iowa, although it is not uncommon in the tamarack bogs of western Wisconsin in Trempleau county and some parts of La Crosse county.

Osmunda cinnamomea L., the Cinnamon Fern, is common in the bogs in Wisconsin, Minnesota, and Michigan, but does not occur, so far as I know, anywhere in the bogs of Allamakee, Clayton, Cerro Gordo, Worth and Winnebago counties. The same may be said of the Royal Fern (O. regalis).

Ophioglossum vulgatum L., though reported both in northern and southern Michigan has not been reported from western Wisconsin or eastern Minnesota, nor from any of the bogs of northern Iowa.

Lycopodium inundatum has been reported from Michigan and is more abundant in bogs eastward but especially northward.

Larix laricina (Du Roi), Koch., the Tamarack, has not been reported from any point in the state of Iowa, although there is a small grove in Houston county across the line in Minnesota and isolated groves in Wisconsin near La Crosse. This is practically the only conifer found in the bogs of that region. Further northward in Wisconsin, Minnesota, and Michigan, the Black Spruce, the Balsam Fir, and Arbor Vitæ occur and eastward in the Dismal Swamp country and as far north as Massachusetts the White Cedar is also a predominant species of the peat bog flora. Strange as it may seem the Balsam Fir, although native to Allamakee county in Iowa is found on cold, wet, limestone rocks, the rocks being covered with Hypnum and other mosses. Nowhere in the state does the Juniper occur and yet in parts of Wisconsin and Michigan there are certain types of bogs in which the Juniper is a common species.

Salix candida Fl., the White Bog Willow, is one of the most interesting of the willows in Iowa. It is not nearly so widely distributed as some of the other species but is characteristic of 
some of the bogs in Worth, Cerro Gordo and Clayton counties and is likewise abundant in the tamarack and sphagnum bogs of western Wisconsin and southern Minnesota. It does not occur in Hamilton or Emmet counties nor in the bogs near Forest City or in Wright county.

Salix pedicellaris Pursh. This willow, like the preceding, grows in many of the bogs in Cerro Gordo, Winnebago, Worth

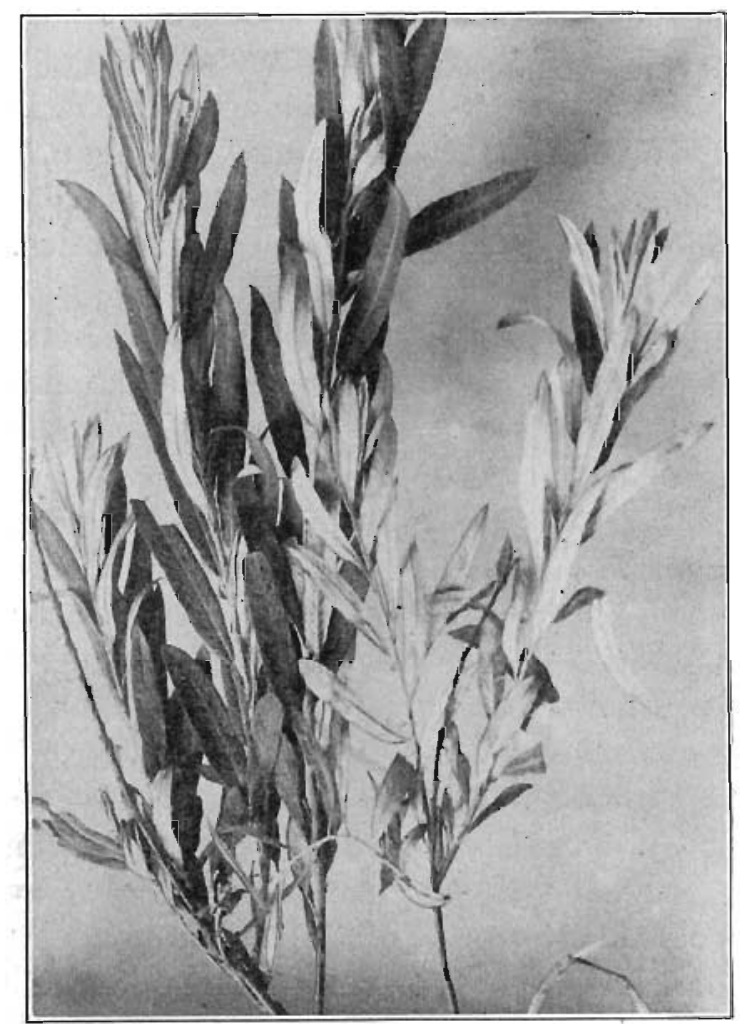

Figure 109. Hoary Willow (Salix candida Fluegge), a bog plant of Worth county. and Emmet counties, always growing where there is a large, supply of water, like the preceding species.

Salix lucida Muhl., the Shining Willow, is less widely distributed than the preceding species; in this state it occurs in a few bogs in Buchanan county and in Linn county, according to Lazell, and occasionally eastward. It is fairly abundant in the sphagnum bogs in the vicinity of La Crosse, Wisconsin. 
Salix rostrata Richards, the Beaked Willow, is nearly as widely distributed as the Salix discolor (Muhl.) or the Glaucous Willow. These willows are common throughout northern Iowa, especially in bogs near springs and where excavations have been made or ditches run through the bogs. They are adapted to somewhat drier conditions than the willows mentioned previ-

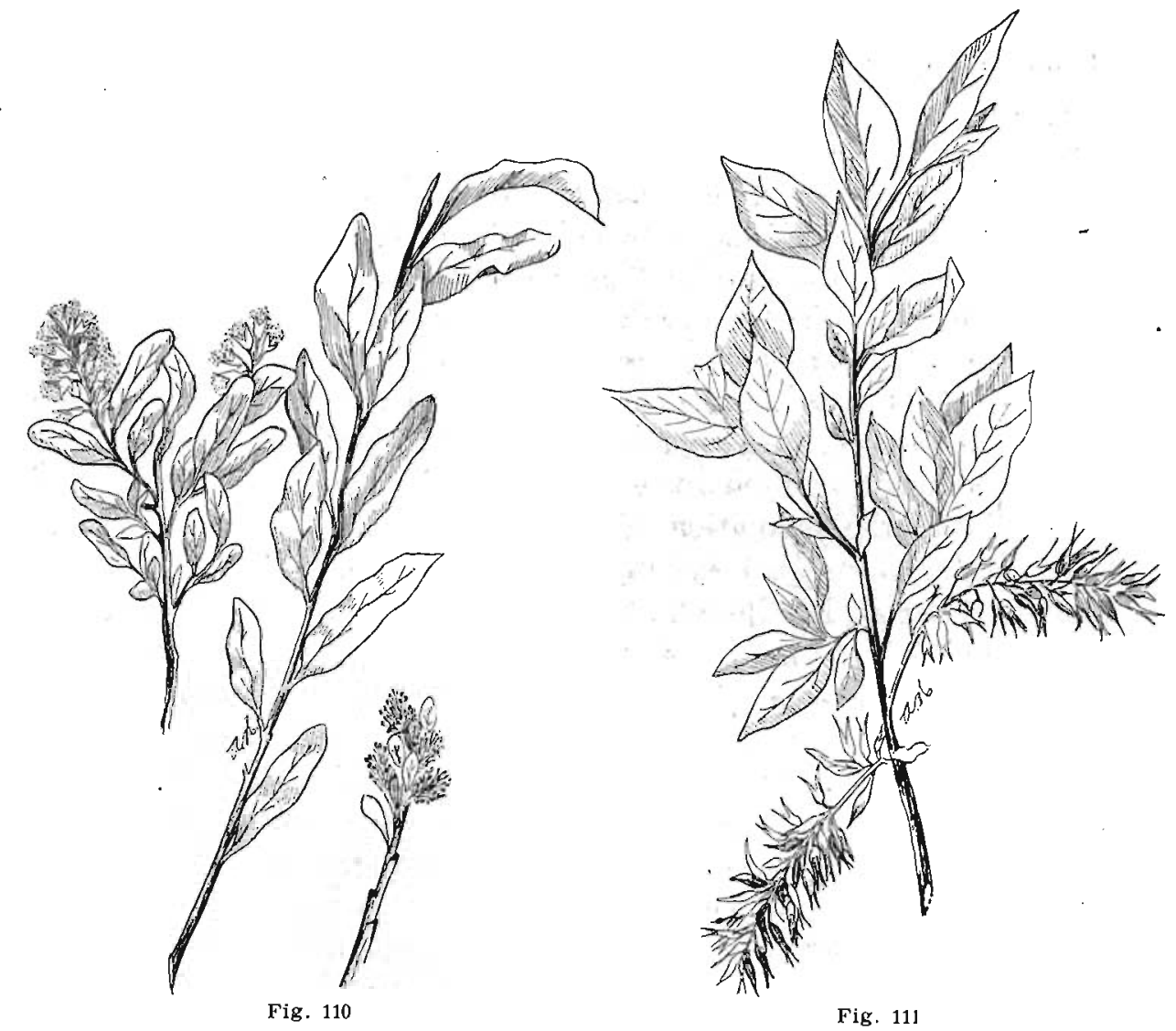

Figure 110. Bog Willow (Salix pedicillaris Pursh.). Drawn by Ada Hayden. Figure 111. Beaked Willow (Salix rostrata Richards). Drawn by Ada Hayden.

ously. These willows are characteristic of some bogs as far south as Boone and Story counties but rarer southward.

Populus tremuloides Michx., the Quaking Asp, is rather frequent on the islands and high grounds adjacent to the peat bogs near Lake Mills, Forest City, Fertile, and other places in northern Iowa. It is a typical constituent of the bog near Wheeler- 
wood, being associated with $S$. discolor and $S$. rostrata. Davis also mentioned its occurrence in the bogs of southern Michigan and along with it he also mentions the Populus grandidentata which though common in northern Iowa, especially northeastward, does not occur in bogs.

Rumex britannica L., the Great Water Dock, is easily recognized during midsummer and late fall by its long fruiting panicles above the sedges and other smaller plants. This dock was common in all the bogs in the counties mentioned above and it is also common eastward in Butler, Chickasaw, Clayton counties in Iowa, and La Crosse county in Wisconsin.

Of the grasses perhaps the most interesting and abundant in the Iowa bogs are Glyceria nervata, Calamagrostis inexpansa, Bromus kalmii, Zizania aquatica, Phragmites communis, Glyceria fluitans and G. grandis. These species are common in Wisconsin, Minnesota, and Michigan as well as Iowa.

Glyceria nervata (Wild.) Trin., the Fowl Meadow Grass, is abundant in moist meadows throughout the region and much more abundant than the two preceding species and is much more important in the formation of peat.

Glyceria fuitans (L.) R. Br., like the Reed Grass, is found in shallow water and although abundant in many places is not so important in the formation of peat as Wild Rice or Reed Grass. It is common throughout the region and extends much farther southward. Along with it we also found frequently, in conditions that do not bespeak of peat, the Glyceria grandis Wats.

Zizania aquatica $\mathrm{L}$. Wild Rice was once quite common in the bogs throughont northern Iowa and may still be found in shallow water under much more moist conditions than the willows or thist]e, in Cerro Gordo, Hamilton, Emmet, Worth, Wright, and Winnebago counties. Where this plant occurs the bog assumes the character of a quaking bog.

Phragmites communis Trin. This Reed Grass grows in situations similar to Wild Rice, often where water stands through the entire season. It has long rootstocks running under the surface of the ground for considerable distances and these form an important constituent of the peat. 
Of the sedges in bogs the most important in northern Iowa is the Carex filiformis, along with C. stricta, C. trisperma, and other species. These constitute perhaps the most important bog sedges in this state. These species likewise constitute an important part of the bog flora of Michigan and. Wisconsin.

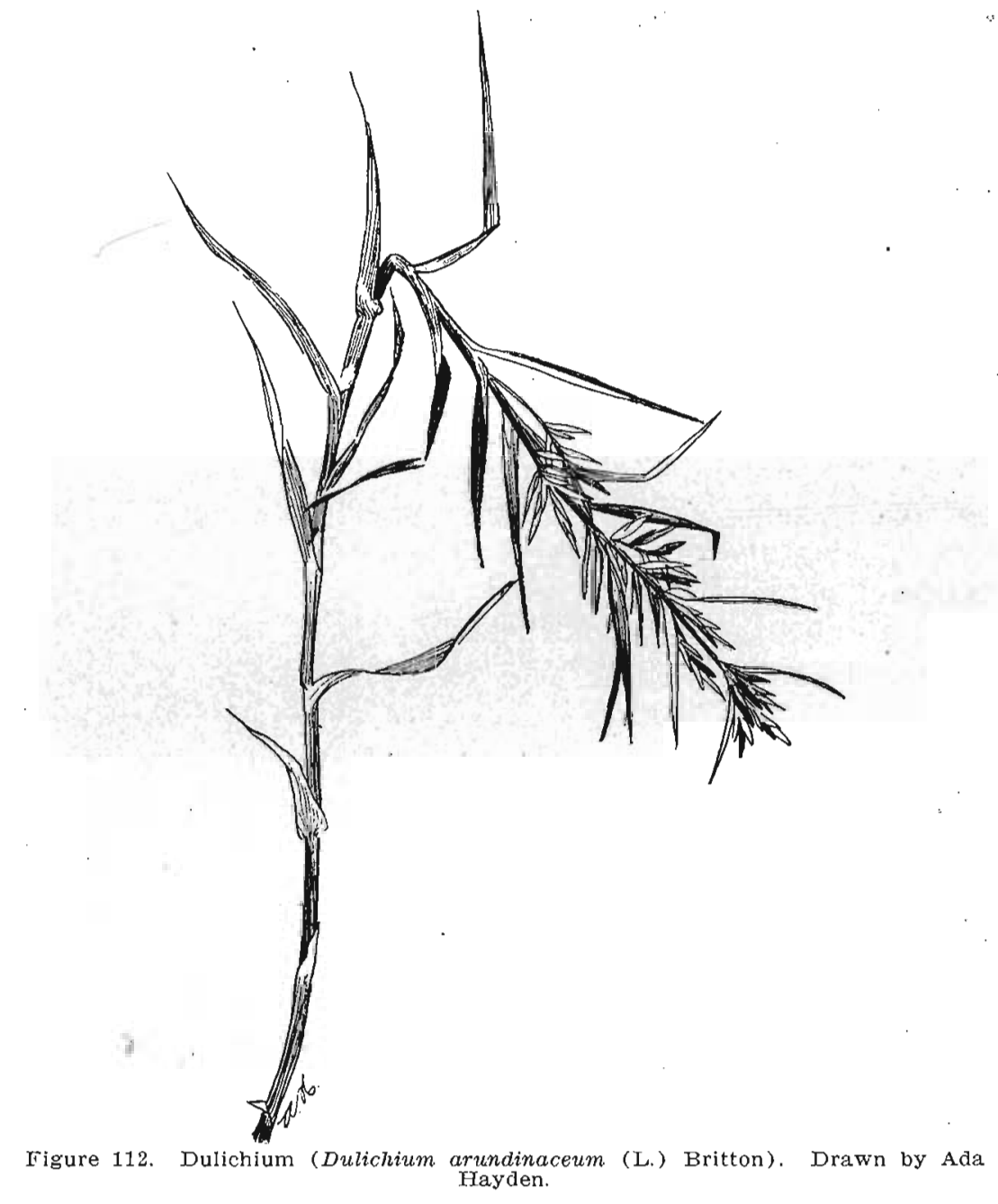

Carex filiformis L. This Sedge is the most important of the bog plants, forming extensive mats which give away as one walks over them. This species has long, tough, narrow leaves, tapering to a thread-like point and forming a horizontal rhizome which 
during the spring, when there is an abundance of moisture, is partially aquatic. These rhizomes increase in length by bearing a terminal bud at the end. The method of formation, along with that of other sedges, has been described by Davis." This sedge was found in Cerro Gordo, Worth, Winnebago, Wright, Hamilton, and Emmet counties, also in northeastern Iowa and western Wisconsin. Other species of sedges grow in the same manner and produce similar mats. The species occurring in northern Iowa are given under the table.

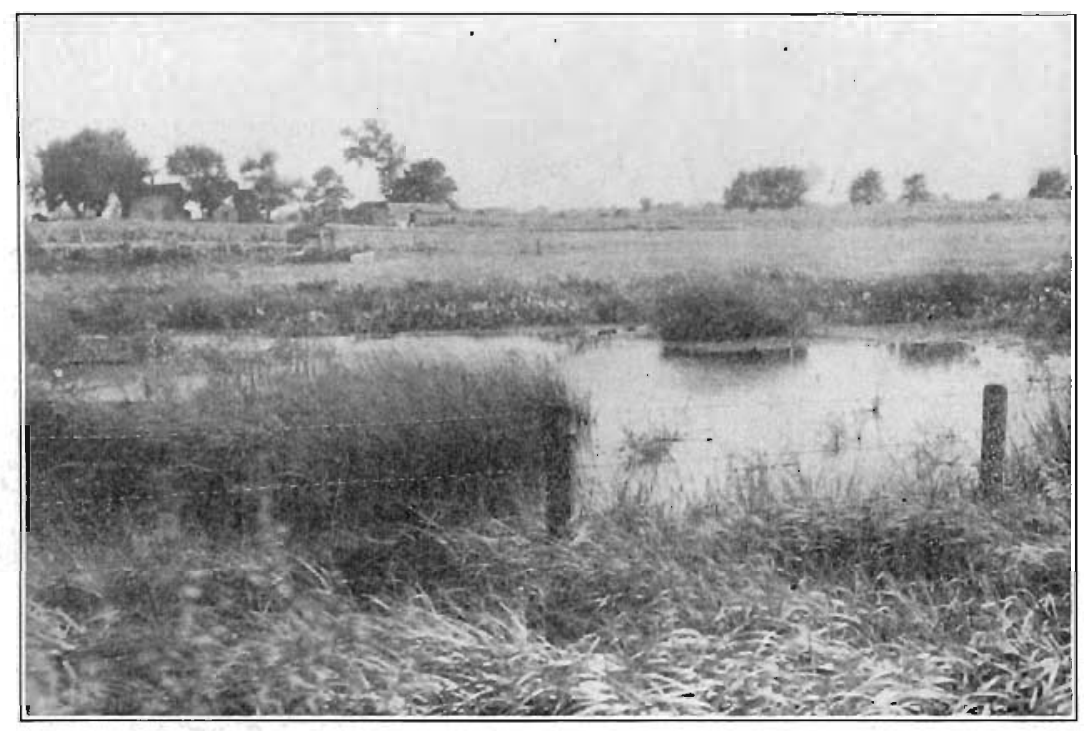

Figure 113. Great Bullrush (Scirpus validus Vahl,) on margin of pond in central Yowa. Photograph by Charlotte M. King.

Dulichium arundinaceum, common everywhere in bogs and moist places in Wisconsin, is confined particularly in this state to the peat bog regions, althougl there are small peat bogs in the vicinity of Ames where this species is not present. It reaches its greatest development from Cerro Gordo county eastward.

Scirpus validus, typical everywhere in bogs, especially where there is standing water in this state, is quite as characteristic in Wisconsin and Minnesota as it is in Iowa. We have only to mention here two other sedges with grass-like leaves, the Eleo-

*Loc. cit., p. 136. 
charis acicularis, which is confined more especially to the muddy flats where there is a considerable mixture of grass and trees, while the $E$. palustris is more widely distributed.

The Cotton Grass is represented in Iowa by two species, while there are four eastward. Rynchospora is not represented in the peat bogs although abundant in the sphagnum bogs of Wisconsin.

Some members of the family Liliaceæ are entirely absent from the state. The Wild Turk's-cap (Lilium canadense) and $L$. philadelphicum occur less frequently in these bogs than in the Wisconsin bogs. In that state there occur not only these lilies, but also the Allium tricoccum and the Smilacina and Maianthimum.

The Wisconsin bogs have three Cypripediums, and three or four Habenarias. The $H$. psychodes is entirely absent from the bogs of northern Iowa, though occurring, according to Mr. Lazell, in Lian county. The Pogonia and Calopogon are abundant and characteristic of sphagnum bogs of Wisconsin and Michigan but do not generally occur in Iowa though reported from Linn county by Mr. Lazell. Of the Smartweed Family the Rumex britannica is characteristic of all the bogs in Wisconsin, Michigan and northern Iowa but in Hamilton county is not as abundant. The Polygonum acre is common in all of our Iowa bogs while the Shoe-string or Tan Weed occurs under somewhat drier conditions. The Polygonum amphibium is abundant not only in Wisconsin but in northern Iowa and Michigan. Two species of Polygonum, $P$. sagittatum and $P$. arifolium, are not recorded for the bogs of northern Iowa, although abundant for the bogs of Wisconsin, Minnesota, and Michigan. The former is found occasionally in Iowa as in Linn county where it has been reported by Mr. Lazell.

One may look upon certain members of the Rose Family as characteristic of the bogs and of these plants mention may be made of the Chokeberry (Pyrus arbutifolia), common in the bogs northward and in Minnesota, Wisconsin and Michigan, occurring on limestone rocks in Iowa. The Shrubby Cinquefoil (Potentilla fruticosa) is common in some bogs in Wisconsin, Michigan, and 
Minnesota, but not in Iowa, although occasionally found in Winneshiek county, according to Shimek.

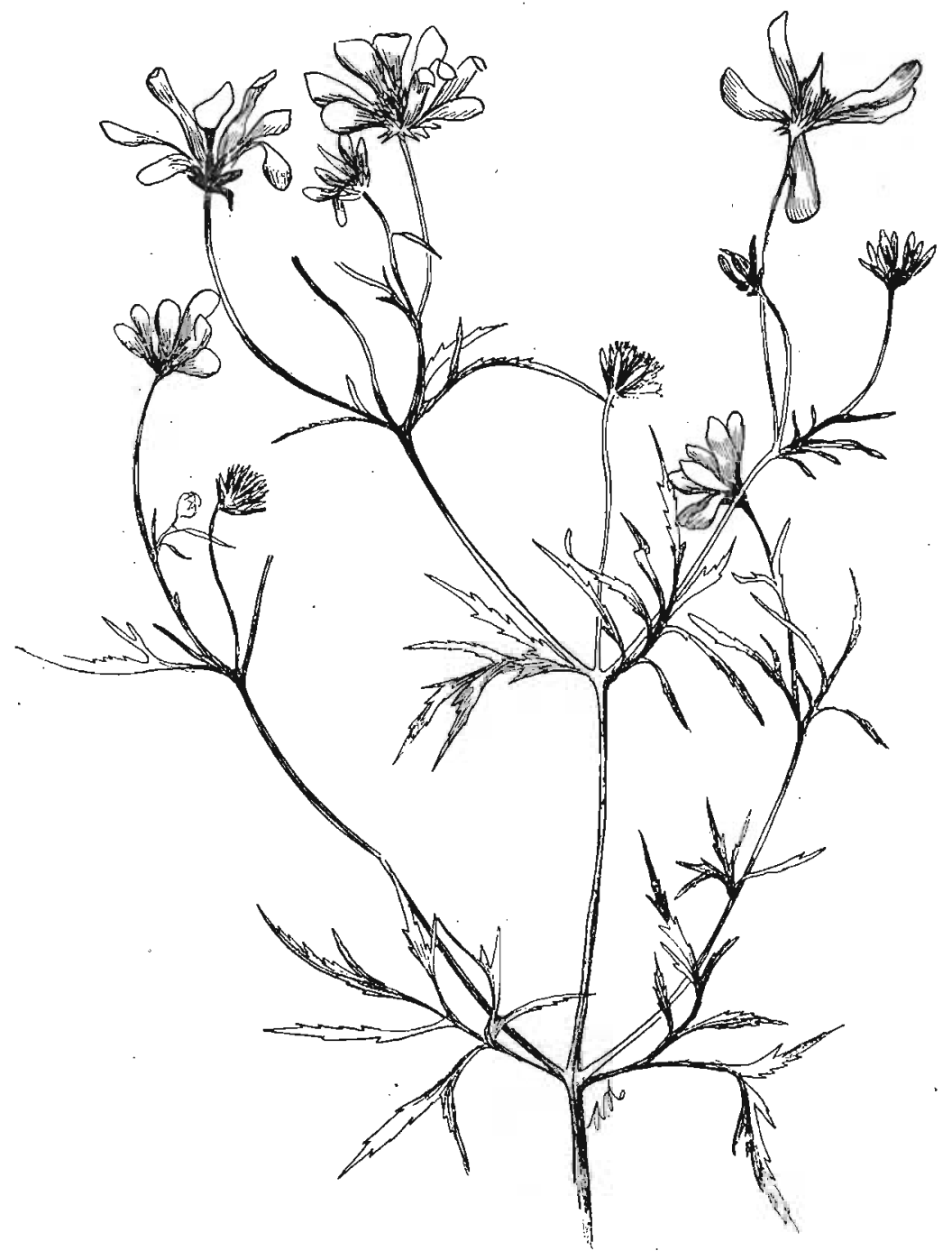

Figure 114. Tickseed Sunflower (Bidens trichosperma (Michx.) Britton). Drawn by

Potentilla palustris. The Marsh Cinquefoil is common throughout the region in Iowa from Winnebago, Emmet, and Worth counties, extending to Cerro Gordo county, and is abundant in the bogs of southern Minnesota, western Wisconsin, and Michigan. This is one of the most typical Iowa bog plants and 
is fairly abundant. The same may be said of the Sphagnum bogs of Wisconsin. It is rather interesting to note that it does not occur on the higher bogs where the Cirsium muticum, Valeriana edulis, Castilleja coccinea occur in western Wisconsin.

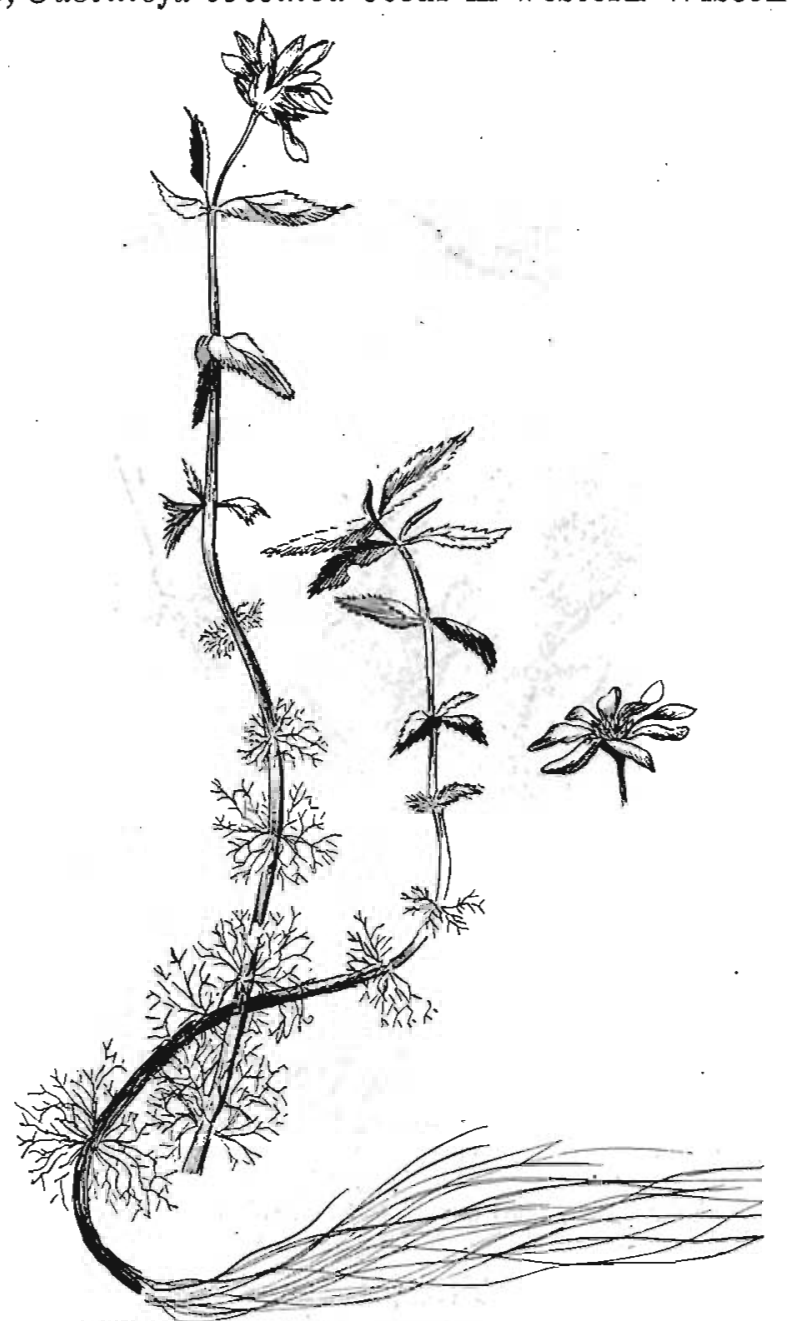

Figure 115. Water Marigold (Bidens beckii Torr.). Drawn by Ada Hayden.

Spiraea salicifolia, the Meadow Sweet, is common in some bogs of northeastern Iowa, but does not reach as far south as Hamilton county, or for that matter is not common in any of the bogs in Cerro Gordo, Worth, and Winnebago counties.

Saxifraga pennsulvanica. This Saxifrage is common in the drier bogs of western Wisconsin and also occurs in the bogs of 
Cerro Gordo, Worth, and Winnebago counties, along with Lobelia kalmii, Epilobium molle, and Cicuta bulbifera. It also occurs in Linn county (Lazell).

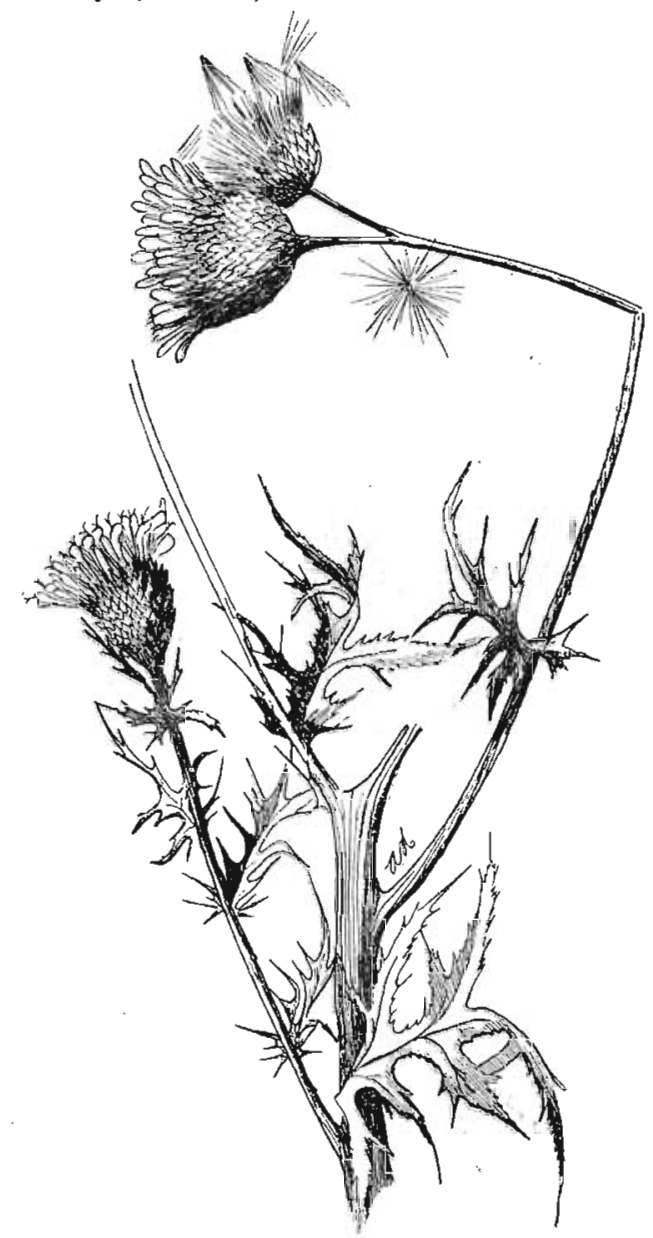

Figure 116. Swamp Thistle (Cirsium muticum Michx.). Drawn by Ada Hayden.

Sarracenia purpurea, Drosera rotundifolia, Rhus vernix and Nemopanthus mucronata, though characteristic of the Sphagnum bogs of Wisconsin and Minnesota, are not represented in this state.

Bidens trichosperma, the Marsh Marigold, occurs in nearly all peat bogs in many of the northern counties of the state, notably in Cerro Gordo, Winnebago, Worth and Hamilton counties. It is 
so characteristic that without the presence of any other plant one is certain that peat occurs. It does not, however, occur in Emmet county. This same plant is common in the peat bogs of Wisconsin and southern Minnesota.

Cirsium muticum Michx., the Swamp Thistle, is characteristic of the type of bog occurring in Cerro Gordo county, near Wheelerwood, also near Fertile and near Lake Mills in Winnebago county, but it does not occur in Emmet, Hamilton, and Wright counties. It also occurs in the drier bogs of southern Minnesota and near La Crosse, Wisconsin.

Bidens cernua $\mathrm{L}$. This plant is rather common in many of the peat bogs, more abundant where they have been drained than in other situations. In one case more than 160 acres were a mass of golden yellow. Otherwise it usually occurs on higher and drier ground. The $B$. connata is also of frequent occurrence near brooks and in moist soil.

Eupatorium perfoliatum L. The common Boneset is one of the most characteristic plants of all the bogs. This is true not only of the drier bogs in Wisconsin but of those throughout northern Iowa. The E. purpureum L. is another characteristic bog plant in all the bogs considered in Iowa and Wisconsin, though somewhat more rare in the Sphagnum and Tamarack bogs.

Aster junceus Ait. The Marsh Aster is characteristic of the larger bogs in Worth and Winnebago counties and is likewise characteristic of the bogs in Wisconsin.

Solidago riddelli Frank. The species is rather common in central and northern Iowa and abundant in the peat bogs of northern Iowa.

\section{A COMPaRison OF IOWA PEAT Bogs and THOSE OF OTHER PLACES}

In a general survey as given in the table of plants from these different regions it is evident that a large number of the more typical of the peat bog plants of the more northern region are replaced by plants of a totally different character. For instance, the peat bogs of the higher and drier types such as we find in Wisconsin, are almost characteristic of the peat bogs of 
northern Iowa, with the exception of the abundance of Salix candida and S. pedicellaris which do not occur in these bogs although they are abundant in the moist bogs adjacent to the other bogs. The species of willow found in Wisconsin in the bogs are much the same as in Iowa with the exception of the Shining Willow which occurs in a few bogs in the Iowan drift

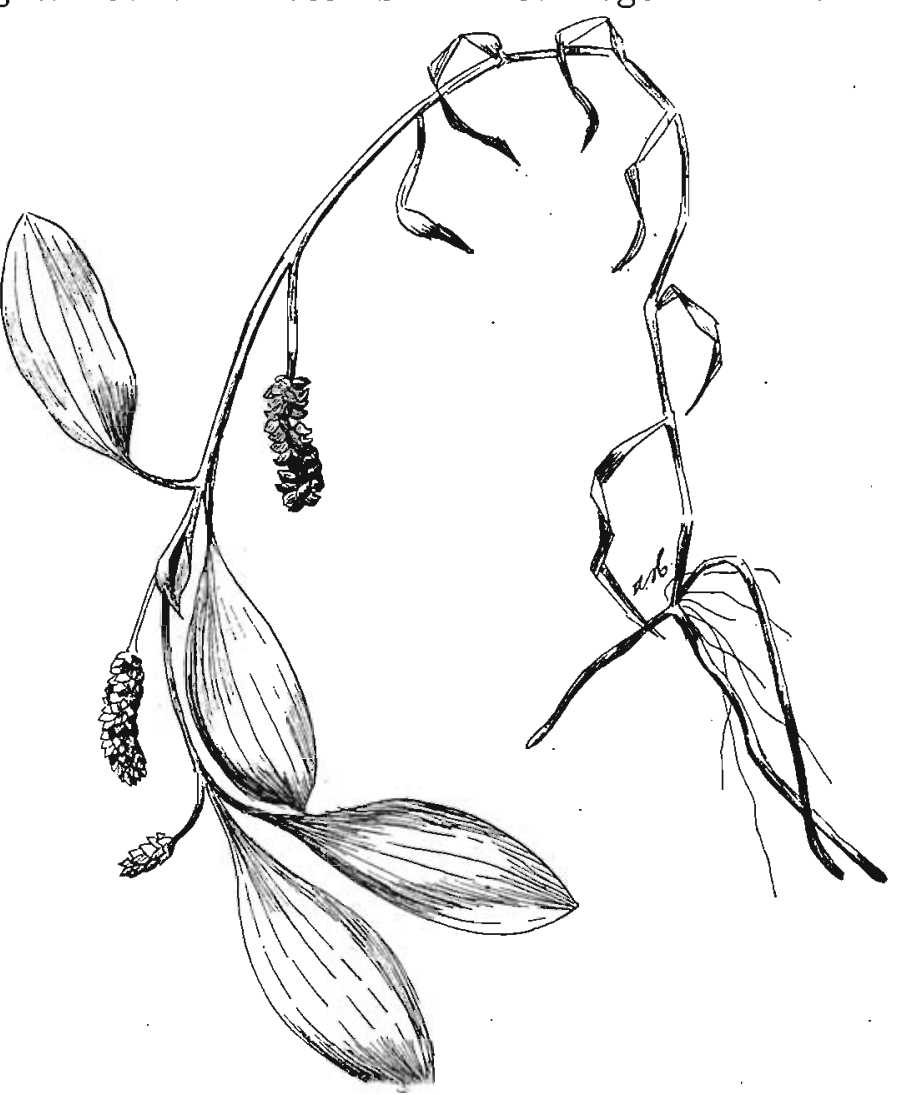

Figure 117. Pondweed (Potamogèton ephihydrus Raf.). Drawn by Ada Hayden.

area in Buchanan, Linn, and Black Hawk counties. The absence of sphagnum and most of the orchids and ferns with the exception of the Aspidium thelypteris is another distinctive feature of the Iowa peat bog flora.

The algal and bacterial flora as well as many other aquatic plants like Scirpus validus and Zizania aquatica are typical for all the regions of northern Iowa and western Wisconsin and so need not be considered in this connection. 


\section{SHRUBS IN IOWA BOGS}

It is rather remarkable that so few of the shrubs have developed in the peat bogs of northern Iowa. The Cornus stolonifera which is so abundant on the edges and borders of tamarack bogs and other peat bogs of Wisconsin is confined to upland banks near lakes and streams in Emmet and the northern Iowa counties. Occasionally two species of Dogwood are found in the drained bogs of this state, namely the Cornus paniculata and C. amomum. In the Dismal Swamp region these are represented by Nyssa and members of the Heath Family. It is rather remarkable to note the absence of heaths in the bogs particularly of northern Iowa; not a single species is represented and yet near La Crosse, Wisconsin, we have one species each of Kalmia, Galussaccia and Gaultheria and one species of the Cranberry (Vaccinium macrocarpon). These same species occur in the peat bogs of Michigan and there is an increase in other species, like Clethra, Andromeda, and Ledum.

\section{INTRODUCED PLANTS IN BOGS}

Drainage of the peat bogs has been attempted in many places in Iowa and in such places a large number of introduced plants have made their appearance. The Small Ragweed (Ambrosia artemisiifolia), Goosefoot (Chenopodium album), Old Witch Grass (Panicum capillare), Pennsylvania Smartweed (Polygonum pennsylvanicum), Pigweed (Amarantus retroflexus), Five-finger (Potentilla monspeliensis), Milkweed (Asclepias syriaca); Boot Jack (Bidens frondosa) and B. discoidea, are representative types. These plants originally did not constitute a part of the bog flora, except in dry years, when they appeared. These are seldom found in the sedge mat where the Marigold (Bidens beckii), Swamp Thistle (Cirsium muticum), Myrtleleaved Willow (Salix pedicellaris) and Lobelia kalmii grow in abundance. 


\section{BIBLIOGRAPHY}

1. Davis, Charles A........Peat: Essays on its Origin, Uses, and Distribution in Michigan. From Rept. State Bd. Geol. Sur. Michigan, 1906. 95-395. pl. 13-\$1. f. 2.25. Lansing, 1907.

2. Shaler, N. S..........Fresh Water Morasses of the United States. Rept. U. S. Geol. Sur. 10. 1890.

3. Lesquereux, L..........Torfbildung im grosses Dismal Swamp. Zeitsch. der deutsch. Geol. Gesellsch. 4. 1852.

4. Kearney, T. H........Report on the Botanical Survey of the Great Dismal' Swamp Region. Cont. U. S. Nat. Herbarium 5: $321-585$.

5. Cowles, H. C.......... The Physiographic Ecology of Chicago and Vicinity. Bot. Gaz. 31: 73-108.

6. Coulter, S. M..........An Ecological Comparison of Some Týpical Swamp Areas. Rept. Mo. Bot. Gar. 15: 39-72. pl. 1-24.

7. MacMillan, Conway...... On the Occurrence of Sphagnum Atolls in Central Minnesota. Minn. Bot. Studies. Geol, and Nat. Hist. Sur. of Minn. Bull. 9: 13.

9. Whitford, H. N........The Genetic Development of the Forests of Northern Michigan. Bot. Gaz. 31: 289-325.

10. Atkinson, G. F.......... Elementary Botany. 444. New. York. 1898.

11. Mills, W. M..........A Physiographic and Ecological Study of the Lake Eagle Region, Indiana. Ann. Rept. Dept. Geol. and Nat. Resources of Ind. 28: (1905).

12. Pieters, A. J...........Plants of Lake St. Clair. Bull. Mich. Fish Com. 2. (1904.)

13. Transeau, E. N......... On the Geographic Distribution and Ecological Relation of the Bog Plant Societies of. Northern North America. Bot. Gaz. 36: 401-420. 3. m.

14. Harshberger, J. W.......Bogs, their Nature and Origin. Plant World. 12: 34-41: 53-61. $5 \mathrm{f}$.

15. Olsson-Seffer, Pehr......Examination of Organic Remains in Post-glacial Deposits. Am. Nat. 37: 785-797.

16. Weld, Louis A..........Botanical Survey of the Huron River Valley. II. A Peat Bog and Moraine Lake. Bot. Gaz. 37: 36-52.

17. Schimper, A. F. W.......Plant Geography upon a Physiological Basis. Trans. by W. R. Fisher. Rev. and Ed. by $P$. Groom and I. B. Balfour. 839. Oxford. 1903.

18. Fruh, J. and Schroeter, C.Die Moore der Schweiz mit Berucksichtigung der Gesamten Moorfrage. Beitr. Geol. Schweiz. Goetsch. Ser. 3, Bern. 1904.

19. Koller, T...........Die Torfindustrie. Wein. 1898.

20. Eiseln, J. C...........Handbuch, oder....Anleitung zur Kenntniss des Torfwesens. Berlin. 1802. 
21. Sendtner, O.........Die Vegetationsverhaltnisse Sud-Bayerns. Munch. 1854.

22. Fischer-Benzon, R.......Die Moore der Provinz Schleswig-Holstein. Ab- . handl. d. naturw. Vereins zur Hamburg. 11. 1891.

23. Weber, C. A..........Ueber die Vegetation des Moores von Augsumal bei Heydekrug. Mitth. d. Vereins zur Forderung d. Moorcultur im Deutschen Reiche. 9. 1894.

24. Christ, H.............Das Pflanzenleben der Schweiz. Basel. 1879.

25. Drude, $0: \ldots \ldots \ldots \ldots \ldots$ Bericht uber die Fortschritte in der Geographie der Pflanzen. 1901-1904. Geographisches Jahrbuch 28: 214-219. 1905. Reviewed by Harshberger, see N. 14.

26. Pammel, L. H.........A Comparative Study of the Vegetation of Swamp, Clay, and Sandstone Areas in Western Wisconsin, Southeastern Minnesota, Northeastern, Central, and Southern Iowa. Proc. Dav. Acad. Sci. 10: 33-126.

Old Lake Vegetation in Hamilton County, Iowa. Pl. World. 2: 42-45.

27. Cratty, R. I...........Flora of Emmet County, Iowa. Proc. Ia. Acad. Sci. 11: 201-251.

28. Shimek, B............. Flora of Winneshiek County, Iowa. Ia. Geol. Sur. 16: 147-234. 
